\title{
Report on Oak Ridge National Laboratory Testing of Southwire 795 C7 Round Wire
}

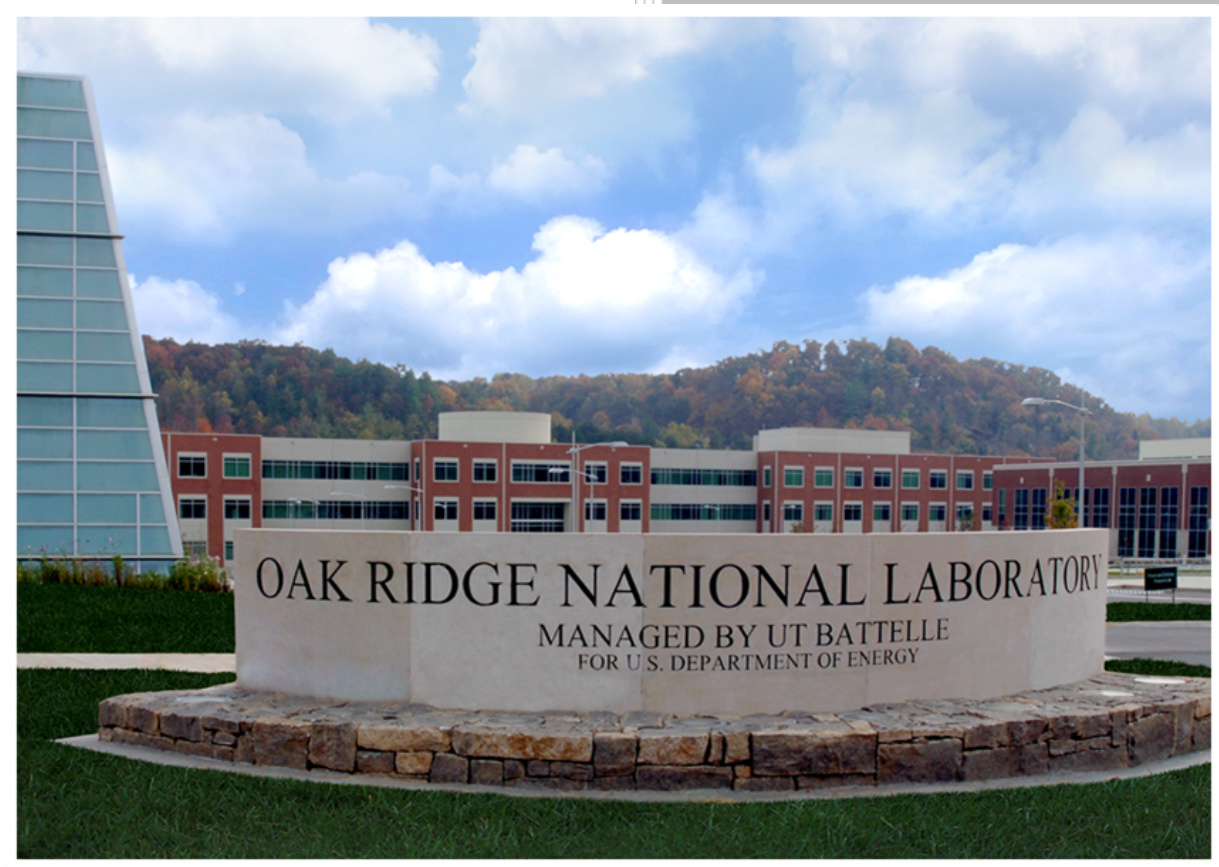

Philip Irminger

Dan King

Drew Herron

Greg Sheets

Phil Overholt

Zhi Li

Graham Pash

September 2018 


\title{
DOCUMENT AVAILABILITY
}

Reports produced after January 1, 1996, are generally available free via US Department of Energy (DOE) SciTech Connect.

\section{Website www.osti.gov}

Reports produced before January 1, 1996, may be purchased by members of the public from the following source:

\author{
National Technical Information Service \\ 5285 Port Royal Road \\ Springfield, VA 22161 \\ Telephone 703-605-6000 (1-800-553-6847) \\ TDD 703-487-4639 \\ Fax 703-605-6900 \\ E-mailinfo@ntis.gov \\ Website http://classic.ntis.gov/
}

Reports are available to DOE employees, DOE contractors, Energy Technology Data Exchange representatives, and International Nuclear Information System representatives from the following source:

Office of Scientific and Technical Information

PO Box 62

Oak Ridge, TN 37831

Telephone 865-576-8401

Fax 865-576-5728

E-mail reports@osti.gov

Website http://www.osti.gov/contact.html

This report was prepared as an account of work sponsored by an
agency of the United States Government. Neither the United States
Government nor any agency thereof, nor any of their employees,
makes any warranty, express or implied, or assumes any legal liability
or responsibility for the accuracy, completeness, or usefulness of any
information, apparatus, product, or process disclosed, or represents
that its use would not infringe privately owned rights. Reference herein
to any specific commercial product, process, or service by trade name,
trademark, manufacturer, or otherwise, does not necessarily constitute
or imply its endorsement, recommendation, or favoring by the United
States Government or any agency thereof. The views and opinions of
authors expressed herein do not necessarily state or reflect those of
the United States Government or any agency thereof.


Electrical and Electronics Systems Research Division

\title{
REPORT ON OAK RIDGE NATIONAL LABORATORY TESTING OF SOUTHWIRE 795 C7 ROUND WIRE
}

\author{
Philip Irminger \\ Oak Ridge National Laboratory \\ Dan King \\ Oak Ridge National Laboratory \\ Andrew Herron \\ Oak Ridge National Laboratory \\ Greg Sheets \\ Oak Ridge National Laboratory \\ Phil Overholt \\ Department of Energy \\ Zhi Li \\ Oak Ridge National Laboratory \\ Graham Pash \\ NC State
}

September 2018

Prepared by

OAK RIDGE NATIONAL LABORATORY

Oak Ridge, TN 37831-6283

managed by

UT-BATTELLE, LLC

for the

US DEPARTMENT OF ENERGY

under contract DE-AC05-00OR22725 



\section{CONTENTS}

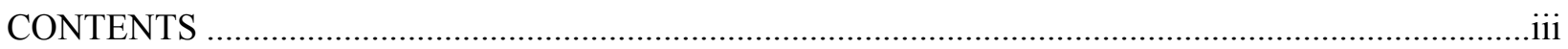

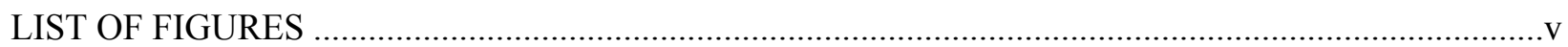

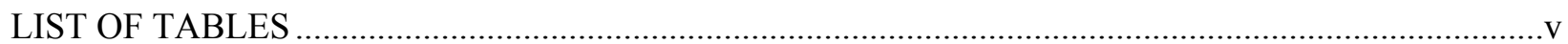

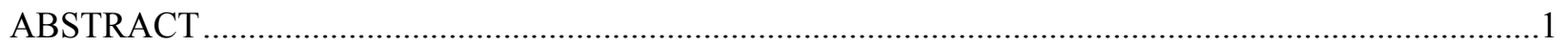

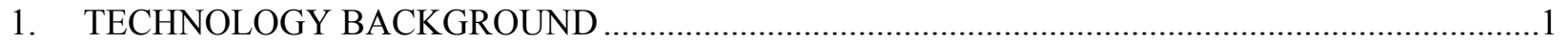

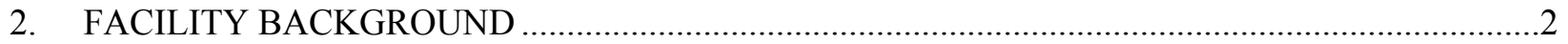

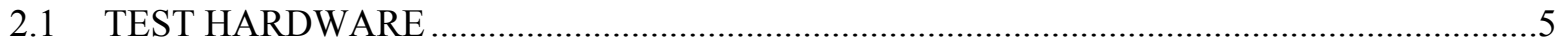

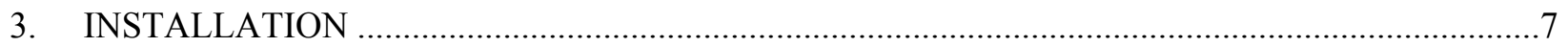

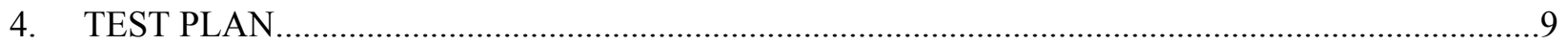

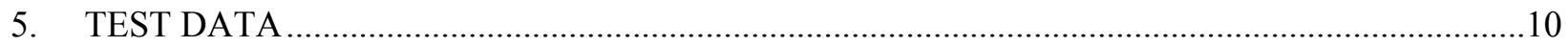

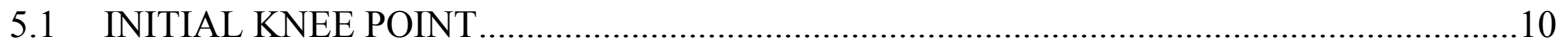

5.2 THERMAL AGING AT RATED CONDUCTOR TEMPERATURE .....................................16

5.3 THERMAL AGING AT EMERGENCY CONDUCTOR TEMPERATURE …......................23

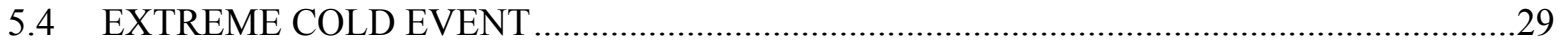

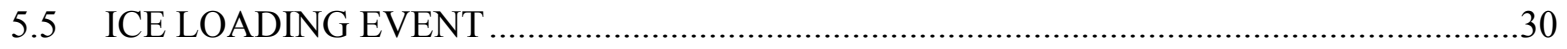

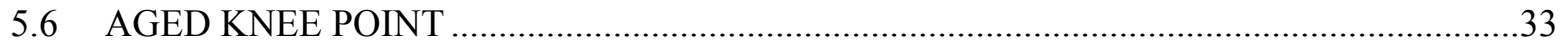

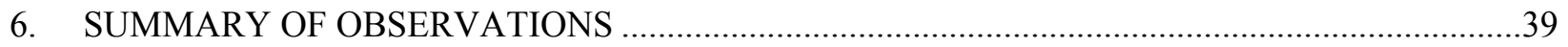

APPENDIX A. CONTROL SYSTEM FOR THE POWERLINE CONDUCTOR ACCELERATED

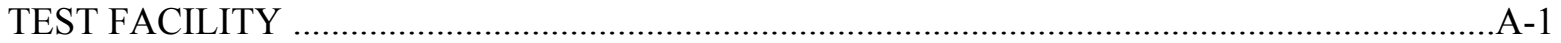

APPENDIX B. THERMOCOUPLE CHANNELS AND LOCATIONS .................................................. 



\section{LIST OF FIGURES}

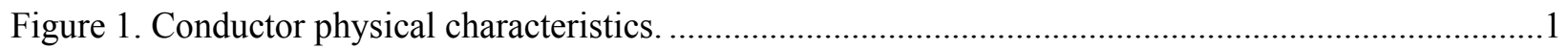

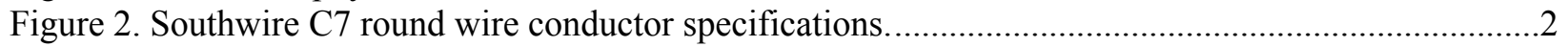

Figure 3. High-temperature, low-sag conductors. (NESC = National Electrical Safety Code).....................3

Figure 4. Increased operating temperatures of high-temperature, low-sag conductors. (ACSR = aluminum conductor steel-reinforced, $\mathrm{ACAR}=$ aluminum cable alloy-reinforced, and $\mathrm{AAC}=$ all-aluminum conductor)

Figure 5. Aerial view of the Powerline Conductor Accelerated Test facility............................................4

Figure 6. Graphical depiction of the Powerline Conductor Accelerated Test facility (side view)...............4

Figure 7. Graphical depiction of the Powerline Conductor Accelerated Test facility (overhead

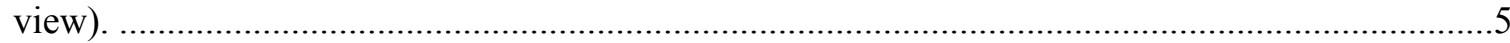

Figure 8. Close-up image of thermocouple attachment to the aerial conductor. .......................................6

Figure 9. Thermocouple locations (eight COYOTE runts and three pole-mount enclosures

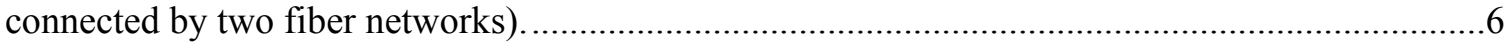

Figure 10. Load cell to convert mechanical force into an electrical signal...............................................

Figure 11. Two reels of the Southwire C7 conductor and one empty reel for the existing aerial

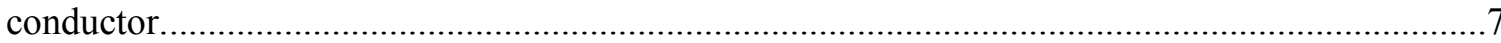

Figure 12. Bull-wheel support at the mid-tower during stringing of the conductor. .................................8

Figure 13. Cable pay-off location during installation showing semi-tension method of installation............9

Figure 14. Initial knee point results for thermocouple channel 6 treeside.............................................11

Figure 15. Initial knee point results for thermocouple channel 6 roadside..........................................12

Figure 16. Initial knee point results for thermocouple channel 9 treeside.............................................13

Figure 17. Initial knee point results for thermocouple channel 9 roadside..............................................14

Figure 18. Initial knee point results for thermocouple channel 11 treeside...............................................15

Figure 19. Initial knee point results for thermocouple channel 11 roadside..........................................16

Figure 20. Thermal aging results for thermocouple channel 6 treeside..................................................17

Figure 21. Thermal aging results for thermocouple channel 6 roadside...............................................18

Figure 22. Thermal aging results for thermocouple channel 9 treeside.................................................19

Figure 23. Thermal aging results for thermocouple channel 9 roadside...............................................20

Figure 32. Conductor temperature, Sag10, and current during extreme cold event. ...............................29

Figure 33. Knee point results at end of testing plotted against thermocouple channel 7 treeside. ...............30

Figure 34. Knee point results at end of testing plotted against thermocouple channel 7 roadside..............31

Figure 35. Knee point results at end of testing plotted against thermocouple channel 10 treeside. ............32

Figure 36. Knee point results at end of testing plotted against thermocouple channel 10 roadside.............33

Figure 37. Knee point results at end of testing plotted against thermocouple channel 11 treeside. .............34

Figure 38. Knee point results at end of testing plotted against thermocouple channel 11 roadside.............35

Figure A.1. Current operating system for the Powerline Conductor Accelerated Test facility.................A-1

\section{LIST OF TABLES}

Table B.1. Thermocouple attachment channels and locations 



\begin{abstract}
A key to industry acceptance of a new technology is extensive validation in field trials. The Powerline Conductor Accelerated Test facility (PCAT) at Oak Ridge National Laboratory (ORNL) is specifically designed to evaluate the performance and reliability of novel overhead conductors and conductor instrumentation under field conditions. PCAT is set up to capture large amounts of data during testing.

Southwire Corporation is a world leader in both overhead and underground electric power transmission products. The company produces high-temperature, low-sag (HTLS) conductors designed for overhead distribution and transmission lines. The HTLS conductors are designed to operate continuously at elevated temperatures up to $250^{\circ} \mathrm{C}$ with no loss of strength, with less sag under emergency electrical loadings than conventional conductors, with excellent self-damping properties, and with final sags that are not affected by the long-term creep behavior of aluminum. Southwire used the PCAT facility to test and validate the performance of the $795 \mathrm{C} 7$ conductor. This report provides initial results of that testing.
\end{abstract}

\title{
1. TECHNOLOGY BACKGROUND
}

The C7 round wire overhead conductor was developed to meet a utility industry need for hightemperature, low-sag (HTLS) conductors that match the affordability and reliability of the aluminum, steel-reinforced (ACSR) and aluminum, steel-supported (ACSS) conductors that have dominated overhead transmission for almost 100 years. Their reliability and safety are expected to exceed the already excellent record of conventional ACSR and ACSS conductors. These improvements were accomplished by using materials that have proved to be rugged, reliable, and long-lived.

Aerospace-grade carbon fibers are used along the length of each reel, as well as the proven thermoplastic polymer matrix PPS and a protective capping layer of PEEK, the toughest, most abrasion-resistant, and most heat-tolerant polymer known (Figure 1). Additionally, a multi-strand core guards against singlepoint failure, and aluminum-zirconium provides an additional layer of full structural redundancy. Since the core is, for practical purposes, immune to chemical attack and corrosion, the life of the conductor is limited only by corrosion of aluminum, which survives for many decades in most outdoor environments. Moreover, the conductor was designed to fit the existing transmission system infrastructure, thus guarding against potential installation errors. See Figure 2 for C7 conductor specifications.

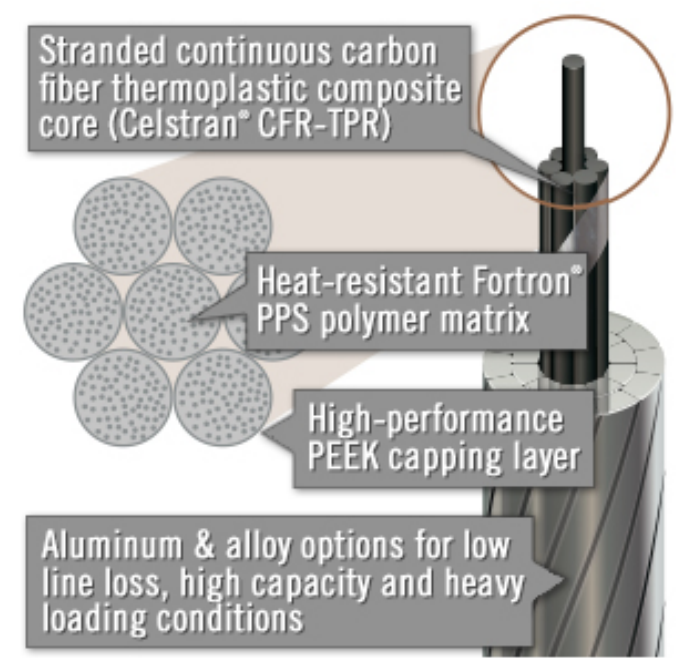

Figure 1. Conductor physical characteristics. 


\section{Overhead Conductor Ampacity}

795.0 C7 Round Wire

\begin{tabular}{|c|c|c|c|}
\hline \multicolumn{2}{|l|}{ Construction Information: } & \multicolumn{2}{|l|}{ Calculation Conditions: } \\
\hline Construction: & Single & Ambient: & $40^{\circ} \mathrm{C}$ \\
\hline Overall Diameter: & $1.108 \mathrm{in.}$ & Wind: & $2 \mathrm{ft} / \mathrm{s}$ \\
\hline Rated Breaking Strength: & $26900 \mathrm{lb}$ & Wind Angle: & $90 \mathrm{Deg}$ \\
\hline Weight: & $.878 \mathrm{lb} / 1000 \mathrm{ft}$ & Sun: & $95.97 \mathrm{Watt} / \mathrm{sq} \mathrm{ft}$ \\
\hline Surface Condition: & Average & & \\
\hline Insulation Thickness: & N/A & Coef of Emissivity: & 0.5 \\
\hline \multirow[t]{2}{*}{ Neutral OD: } & $\mathrm{N} / \mathrm{A}$ & Coef of Absorption: & 0.5 \\
\hline & & Atmosphere: & Clear \\
\hline \multicolumn{4}{|l|}{ Aluminum Info: } \\
\hline Material: & $\mathrm{Al}-\mathrm{Zr}$ & Local Time: & 12 - Noon \\
\hline Conductivity: & $60 \%$ IACS & Date for Local Time: & Jun. 10 \\
\hline Number of Strands: & 26 & & \\
\hline Strand Diameter: & $0.1749 \mathrm{in}$. & North Latitude: & $30^{\circ}$ \\
\hline Strand Factor: & 1.0250 & Azimuth of the Sun: & $0^{\circ}(\mathrm{N}-\mathrm{S})$ \\
\hline Number of Layers of Aluminum: & 2 & Altitude (Above Sea Level): & $0 \mathrm{ft}$ \\
\hline Diameter over Aluminum: & $1.108 \mathrm{in.}$ & Frequency: & $60 \mathrm{~Hz} \mathrm{AC}$ \\
\hline \multicolumn{2}{|l|}{ Core Information: } & \multicolumn{2}{|l|}{ Reactance Information: } \\
\hline Material: & Carbon Fiber & GMR: & $0.0374 \mathrm{ft}$ \\
\hline Conductivity: & $.1 \% \mathrm{IACS}$ & Ind. Reactance (Xa) @ 1ft: & $0.3986 \mathrm{Ohm} / \mathrm{mi}$ \\
\hline Number of Strands: & 7 & Cap. Reactance (X'a) @ 1ft: & 0.0912 MOhm-mi \\
\hline Strand Diameter: & $0.136 \mathrm{in}$. & & \\
\hline Core Diameter: & $0.408 \mathrm{in}$. & & \\
\hline Strand Factor: & 1.0010 & & \\
\hline
\end{tabular}

\begin{tabular}{|c|c|c|c|c|c|c|c|}
\hline \multirow{2}{*}{\multicolumn{2}{|c|}{$\begin{array}{c}\text { Conductor } \\
\text { Temperature }\end{array}$}} & \multirow{2}{*}{\multicolumn{2}{|c|}{$\begin{array}{c}\text { RE S I S T A N C E } \\
(\mathrm{Ohm} / \mathrm{mi})\end{array}$}} & \multicolumn{4}{|c|}{ AMPACITY } \\
\hline & & & & \multirow{2}{*}{$\begin{array}{c}\text { Sun } \\
\text { No Wind }\end{array}$} & \multirow{2}{*}{$\begin{array}{l}\text { No Sun } \\
\text { No Wind }\end{array}$} & \multirow{2}{*}{$\begin{array}{l}\text { Sun } \\
\text { Wind }\end{array}$} & \multirow{2}{*}{$\begin{array}{c}\text { No Sun } \\
\text { Wind }\end{array}$} \\
\hline${ }^{\circ} \mathrm{C}$ & ${ }^{\circ} \mathrm{F}$ & DC & $60 \mathrm{~Hz} \mathrm{AC}$ & & & & \\
\hline 20 & 68 & 0.1176 & & & & & \\
\hline 25 & 77 & 0.1197 & 0.1211 & sest & $* * * *$ & $* * * *$ & $* * * *$ \\
\hline 50 & 122 & 0.1303 & 0.1315 & $x * x *$ & 311 & 175 & 455 \\
\hline 75 & 167 & 0.1409 & 0.1420 & 480 & 628 & 723 & 829 \\
\hline 90 & 194 & 0.1472 & 0.1483 & 651 & 762 & 893 & 976 \\
\hline 100 & 212 & 0.1515 & 0.1525 & 744 & 840 & 986 & 1060 \\
\hline 125 & 257 & 0.1620 & 0.1630 & 937 & 1010 & 1178 & 1237 \\
\hline 150 & 302 & 0.1726 & 0.1735 & 1095 & 1154 & 1334 & 1383 \\
\hline 175 & 347 & 0.1832 & 0.1841 & 1232 & 1282 & 1469 & 1511 \\
\hline 180 & 356 & 0.1853 & 0.1862 & 1257 & 1306 & 1494 & 1535 \\
\hline 225 & 437 & 0.2043 & 0.2051 & 1469 & 1507 & 1700 & 1733 \\
\hline
\end{tabular}

Figure 2. Southwire $\mathbf{C} 7$ round wire conductor specifications.

\section{FACILITY BACKGROUND}

The Powerline Conductor Accelerated Test facility (PCAT) was developed by Oak Ridge National Laboratory (ORNL) and the US Department of Energy (DOE) in 2003 as a test facility to evaluate the performance of novel overhead conductor designs. The objective of these novel conductors is to carry higher currents with the same amount of or less sag in the conductor (Figure 3 and Figure 4). 


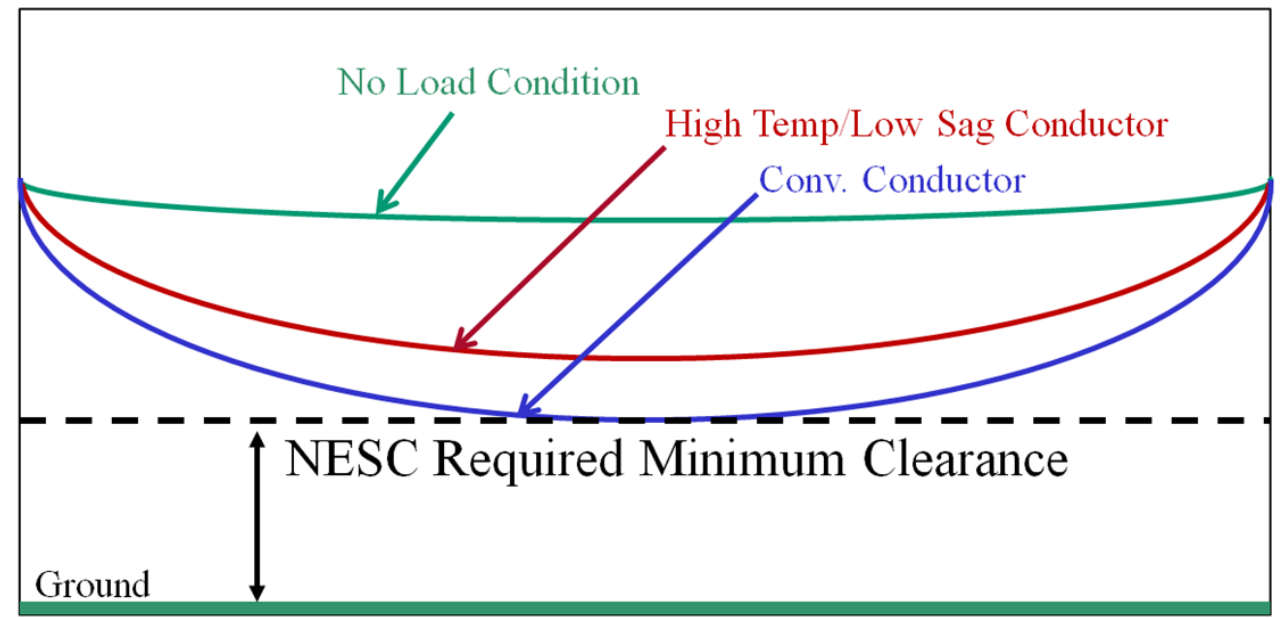

Figure 3. High-temperature, low-sag conductors. $($ NESC $=$ National Electrical Safety Code)

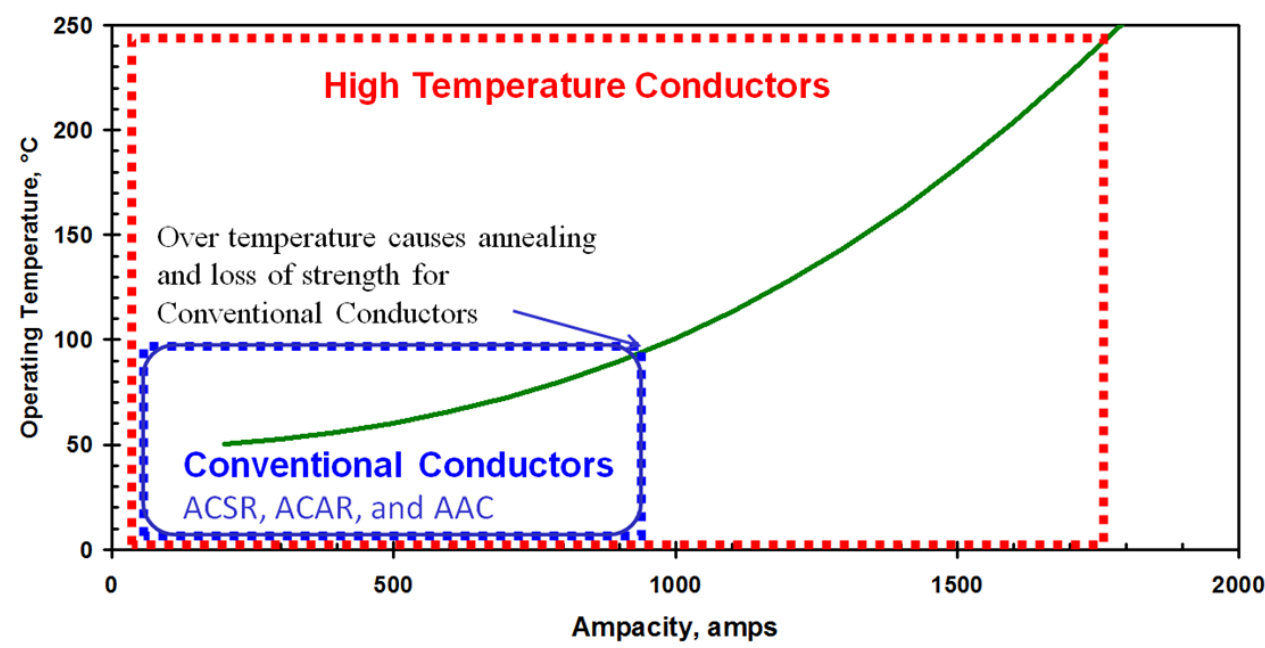

Figure 4. Increased operating temperatures of high-temperature, low-sag conductors. (ACSR $=$ aluminum conductor steel-reinforced, $\mathrm{ACAR}=$ aluminum cable alloy-reinforced, and $\mathrm{AAC}=$ all-aluminum conductor $)$

The facility was originally built to meet guidelines in the 2002 DOE National Transmission Grid Study, which states

DOE will develop national transmission-technology testing facilities that encourage partnering with industry to demonstrate advanced technologies in controlled environments. Working with TVA [the Tennessee Valley Authority], DOE will create an industry cost-shared transmission line testing center at DOE's Oak Ridge National Laboratory (with at least a 50 percent industry cost share).

PCAT has been used to successfully field test overhead conductors and conductor instrumentation to demonstrate and validate performance in a real-world environment either before or in conjunction with field trials. A big hurdle for utility acceptance of novel technologies is field evaluation, and PCAT can provide performance validation through its real-world testing conditions, via which it is able to accelerate the aging of the conductor and test the lifetime. 
PCAT is located at the ORNL campus in Oak Ridge, Tennessee (Figure 5). PCAT provides a high-power, heavily instrumented and controlled platform for performance testing of overhead conductors and conductor instrumentation. This includes collecting all the necessary information for overhead conductor characterization and characterization of whole systems, as well as splices and dead ends. The facility is part of a DOE effort to address growing demands for electric power at a time when existing transmission line capacity is nearing its limits. PCAT is also used to test advanced sensors and controls for overhead conductors. Throughout this report, temperature readings for the conductors

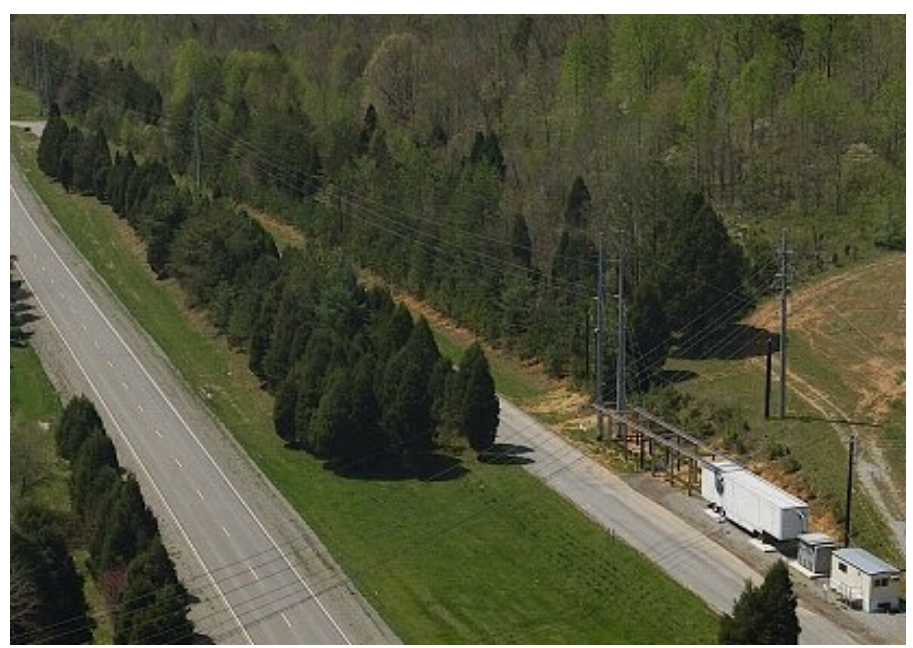

Figure 5. Aerial view of the Powerline Conductor Accelerated Test facility. are labeled "treeside" and "roadside," according to their locations relative to the roadway, as pictured in Figure 5.

PCAT accommodates 2,400 ft of overhead test conductor in a loop arrangement across two $600 \mathrm{ft}$ segments. The facility consists of five $161 \mathrm{kV}$-rated steel transmission poles that have extensive support to ensure mechanical stability, with two poles at each of the two dead ends and one in mid-span. The test line forms the load for the power supply by creating a loop and connecting its two ends to the two terminals of the power source. The power source is a controllable dc power supply that provides dc current up to 5,000 A (Figure 6 and Figure 7).

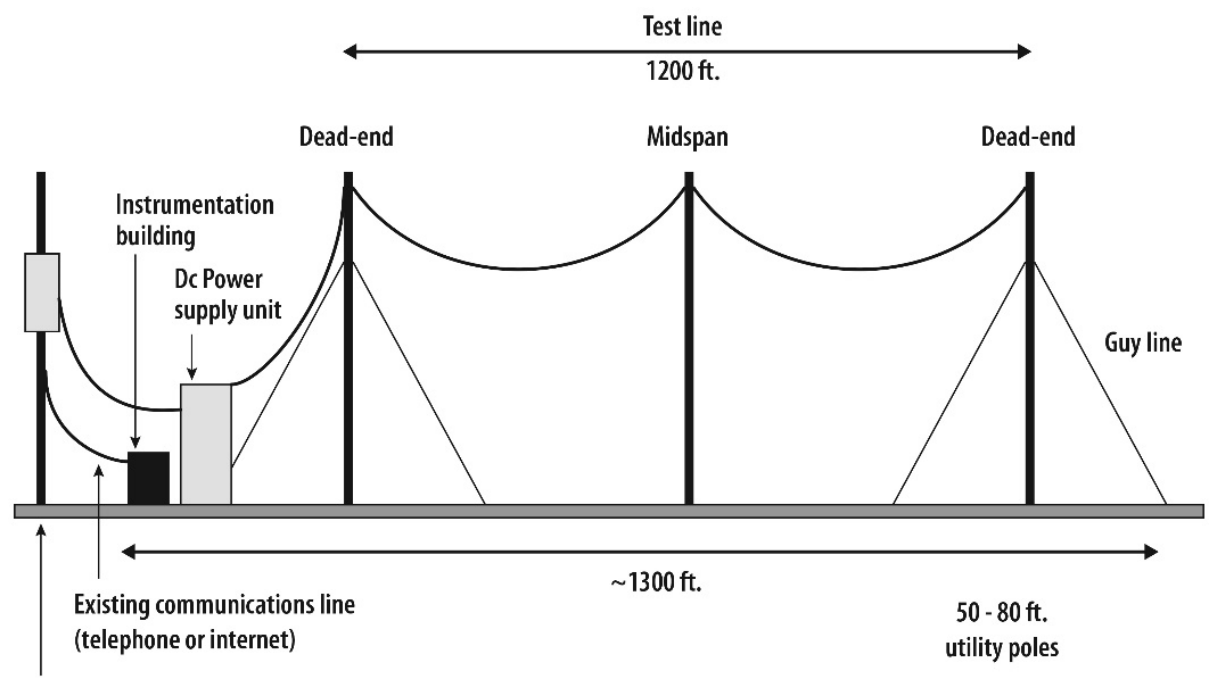

Existing 13-kV distribution line

Figure 6. Graphical depiction of the Powerline Conductor Accelerated Test facility (side view). 
Total length $\sim 1300 \mathrm{ft}$.

DC

Power

De $\quad$ Test conductors

former

supply

$50-80 \mathrm{ft}$

utility poles

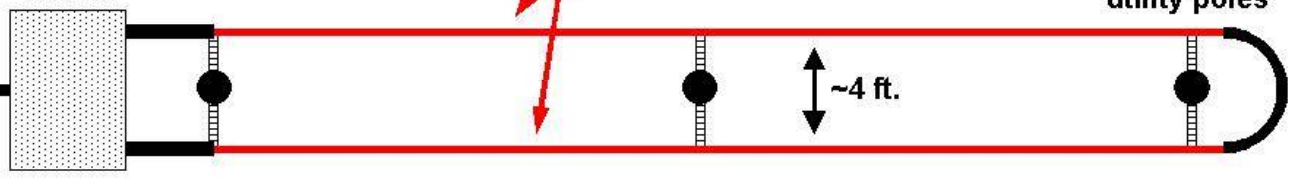

Test Line $=1200 \mathrm{ft} .(2-600 \mathrm{ft}$. spans $)$

Instrumentation shed

Existing communications line

(telephone or internet)

Existing 13.8-kV distribution line

Figure 7. Graphical depiction of the Powerline Conductor Accelerated Test facility (overhead view).

Because all tests at PCAT are at relatively low voltage (typically less than $100 \mathrm{Vdc}$ ), it is possible to place extensive instrumentation in direct contact with the test conductors. Measurement capabilities at PCAT include surface and core temperatures of the conductor under test and simultaneous measurement of conductor voltage, current, tension, sag, and environmental conditions (e.g., wind, solar, ambient). A messenger line with fiber optic loops and a $120 \mathrm{~V}$ instrumentation line are available above the test line to provide control power and communication for instrumentation. (See Appendix A for more information on the PCAT control system and Appendix B for more information on placement of thermocouples at PCAT for conductor surface and core measurements.)

\subsection{TEST HARDWARE}

The following overhead conductor hardware was used in the Southwire 795 C7 testing:

- $\quad 3000 \mathrm{ft}$ Southwire 795 C7 round wire

- Four dead-end clamps

- Two suspension clamps

dc power source. A $2.25 \mathrm{MW}$ controllable dc power source provides current to the test conductor. The power source is fed by a $13.8 \mathrm{kV} / 4,160 \mathrm{~V}$ transformer. The power supply is rated to change the current from 0 to 5,000 Adc and the voltage from 0 to $400 \mathrm{Vdc}$. A manual limit can be set to prevent the power supply from operating above a specified current. A conductor temperature limit, based on the real-time measured conductor temperature, can be set to prevent damage to the conductor and accessories.

Instrumentation. During testing, the following instrumentation elements and measurements provide feedback information for the control system and data collection. 
- Type T thermocouples are placed directly on the conductor surface (Figure 8 and Figure 9).

- Conductor tension measurements are taken by the CAT-1 system using two load cells located on the transmission poles adjacent to the dc power source. The load cell is a transducer that converts the measured force into an electrical signal (Figure 10). Note: These data are combined with the data from the other instruments at midnight of each 24-hour period.

- The current passed through the conductor and the voltage drop are determined by the measured output of the dc power supply.

- A weather station located on the top of the first pole provides ambient temperature, wind speed, wind direction, and solar radiation.

- A net radiation sensor on the CAT-1 system measures the conductor temperature due to ambient conditions.

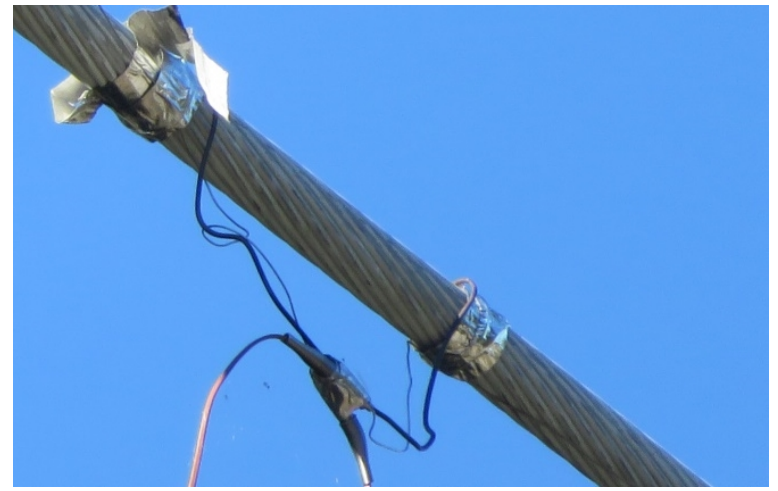

Figure 8. Close-up image of thermocouple attachment to the aerial conductor.

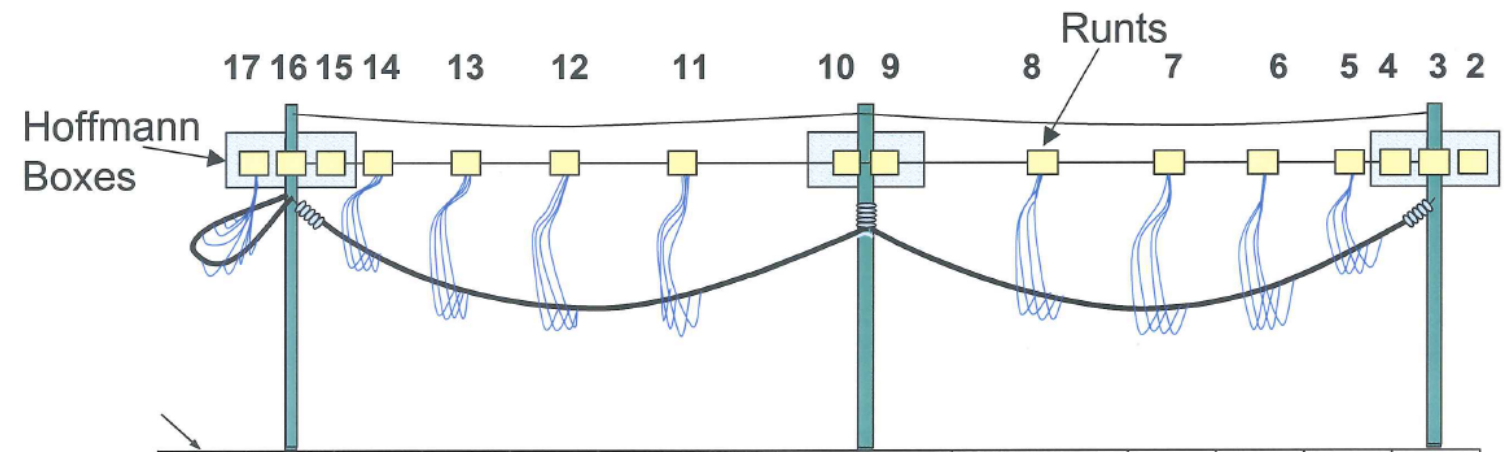

Figure 9. Thermocouple locations (eight COYOTE runts and three pole-mount enclosures connected by two fiber networks). 


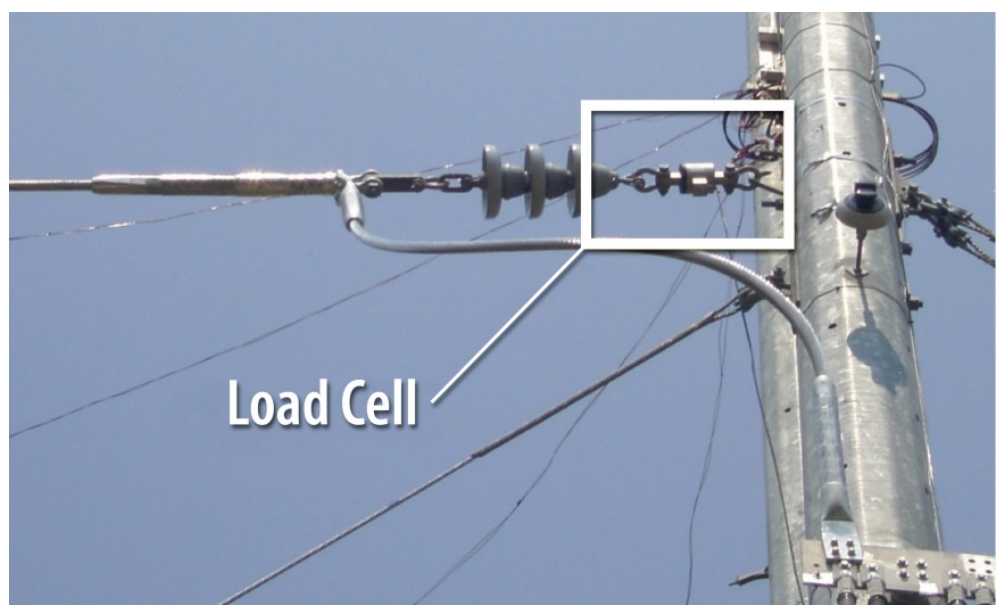

Figure 10. Load cell to convert mechanical force into an electrical signal.

Data acquisition and control system. A PC-based data acquisition and control system is used to capture PCAT data and provide the appropriate control to maintain test set points. This system handles collection of the all instrumentation data and data archival in 1 minute increments.

\section{INSTALLATION}

Installation services were provided by the Tennessee Valley Authority. Southwire provided two reels containing 3,000 ft of 795 Southwire C7 conductor for this installation (Figure 11) along with an empty reel. The reels were inspected before installation, and no damage was found. The conductors were installed by the semi-tension method, pulling straight from the pay-off reel and using the brake to maintain clearance from the ground (Figure 12 and Figure 13).

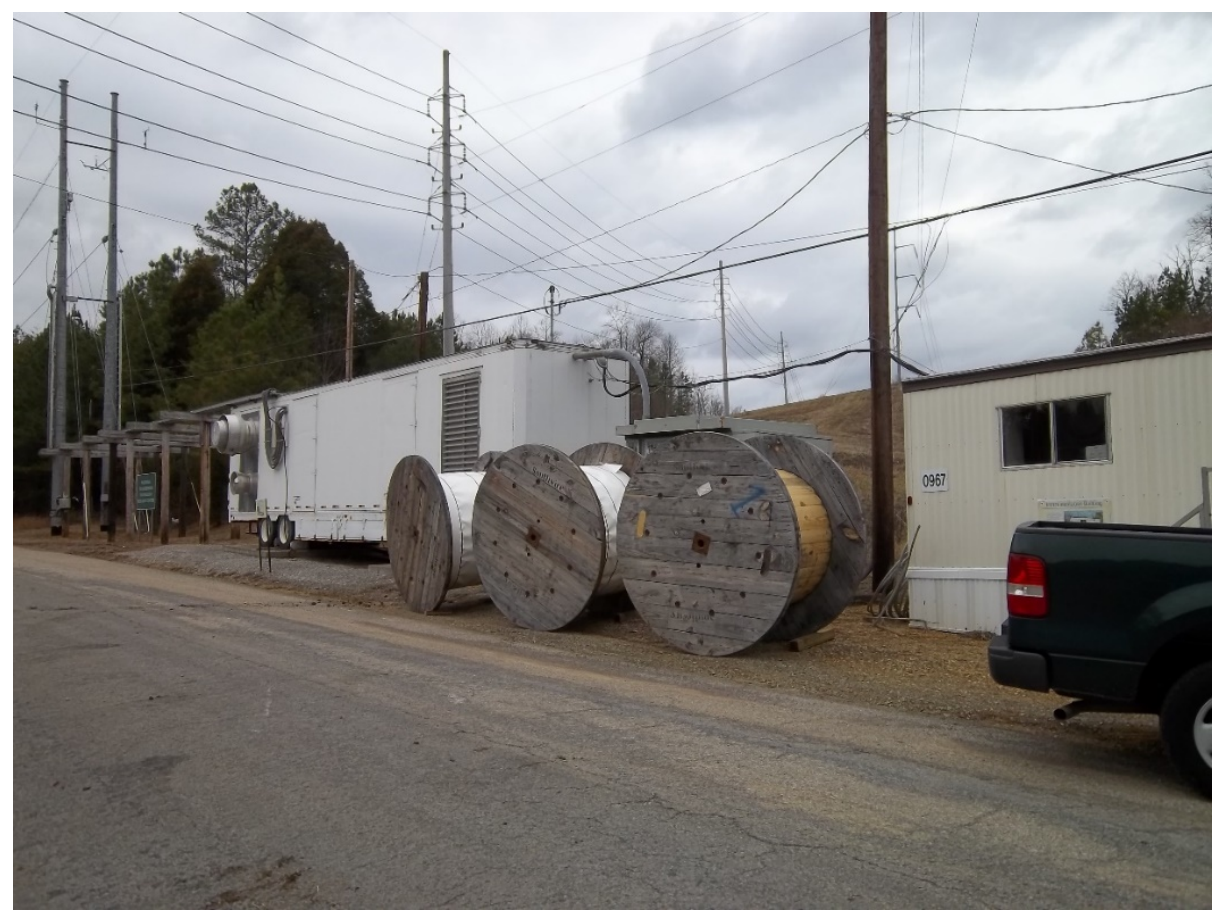

Figure 11. Two reels of the Southwire C7 conductor and one empty reel for the existing aerial conductor. 


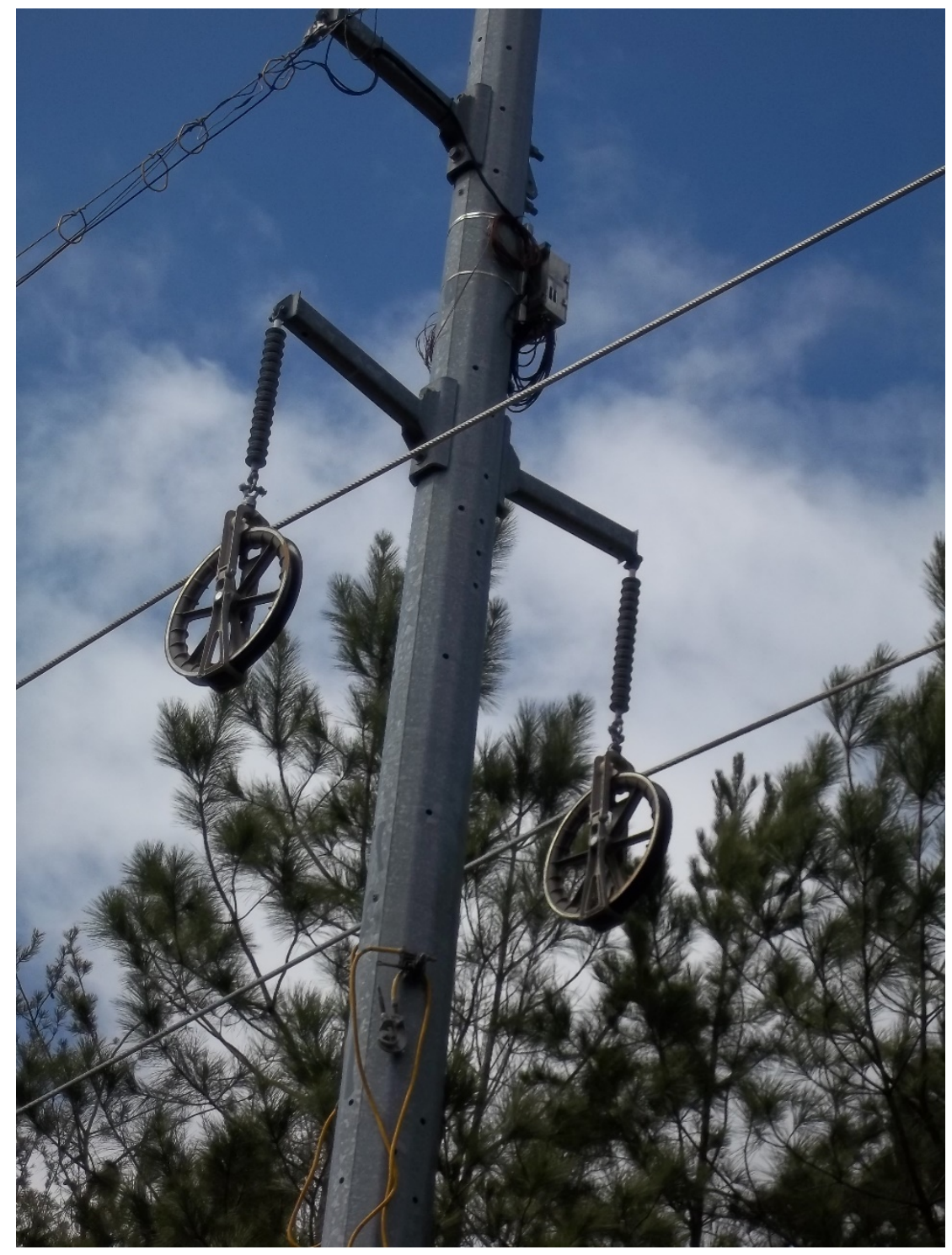

Figure 12. Bull-wheel support at the mid-tower during stringing of the conductor. 


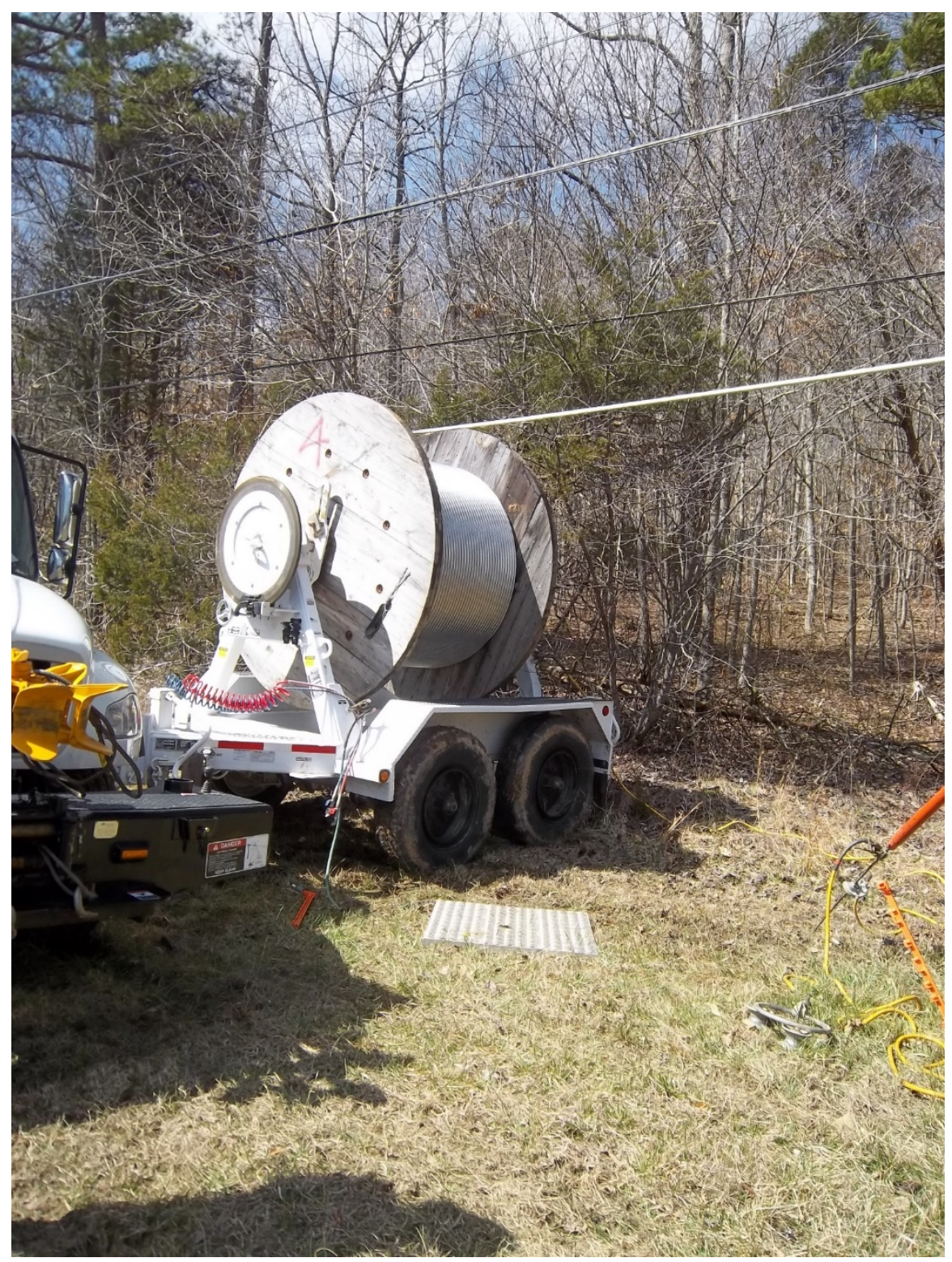

Figure 13. Cable pay-off location during installation showing semi-tension method of installation.

The individual conductors were sagged and clipped in at the same tension to ensure identical installation conditions. The conductors were electrically terminated with compression dead ends using standard installation practices. They were then jumped at the last tower to join the circuit.

During installation, it was noted that the right-of-way was overgrown, so a decision was made to cut the trees back and make a large right-of-way clearing before testing. Once installation was finished, the trees growing into the test line right-of-way were cut back before testing was initiated.

\section{TEST PLAN}

The conductors are being tested according to the following test plan. 
1. Initial knee point. A test 5 to 8 hours in duration measures the conductor knee point (above the knee point temperature, the aluminum strands of an ACSR conductor have no tension or go into compression). Based on the test results, the relationship between conductor temperature and conductor tension is used to identify the knee point temperature. The test data can also be presented as a measured sag and tension curve. To perform the test, the conductor starts at ambient temperature and current is slowly ramped up to heat the conductor. When the conductor has reached its rated operating temperature, the temperature is held for a short period of time and then the current is slowly ramped down. The conductor is allowed to return to ambient temperature.

2. Thermal aging at rated conductor temperature. The conductor is thermally aged at a targeted temperature of $180^{\circ} \mathrm{C}$. During aging, the conductor will accumulate 1500 hours at the target temperature.

3. Thermal aging at emergency conductor temperature. The conductor is thermally aged at a targeted temperature of $225^{\circ} \mathrm{C}$. During aging, the conductor will accumulate 1500 hours at the target temperature.

4. Aged knee point. A test 5 to 8 hours in duration measures the conductor knee point. Based on the test results, the relationship between conductor temperature and conductor tension is used to identify the knee point temperature. The test data can also be presented as a measured sag and tension curve. To perform the test, the conductor starts at ambient temperature and current is slowly ramped up to heat the conductor. When the conductor has reached its rated operating temperature, the temperature is held for a short period of time and then the current is slowly ramped down. The conductor is allowed to return to ambient temperature.

5. Emergency overload conditions. A 15 minute test at $300^{\circ} \mathrm{C}$ is performed to analyze performance during an emergency overload condition.

\section{TEST DATA}

Throughout the collection of test data, temperature measurements are referred to as "treeside" and "roadside." These terms correspond to the geographic location of each measurement on the test line. For each thermocouple module, there will be as many as 4 treeside and 4 roadside measurements available. Many thermocouple channels give noisy data, or come loose from the conductor, so a broad selection of measurements will be shown.

\subsection{INITIAL KNEE POINT}

The knee point test was conducted and resulted in a knee point at around $75^{\circ} \mathrm{C}$. Figure $14-19$ show a representative sampling throughout the conductor. 


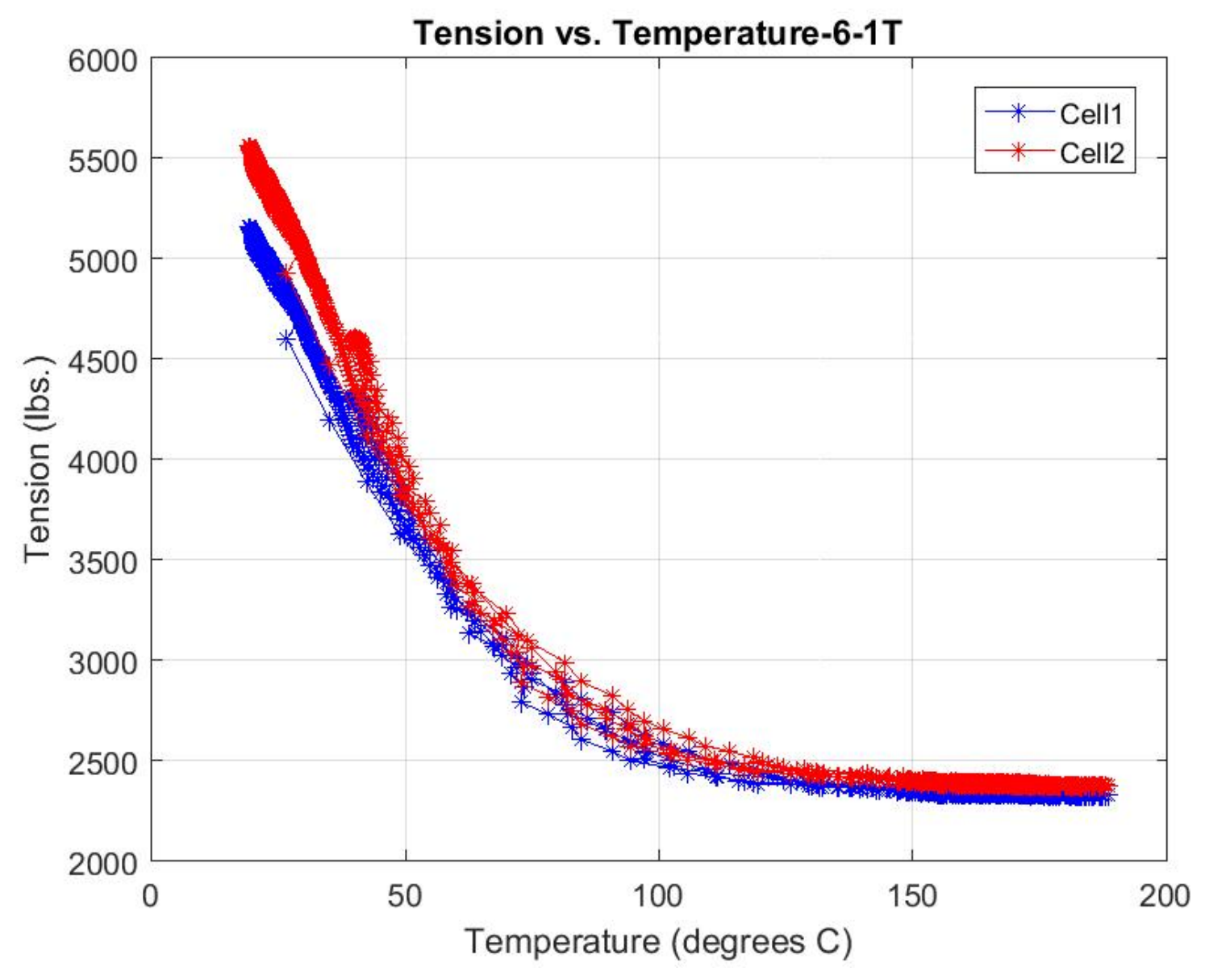

Figure 14. Initial knee point results for thermocouple channel 6 treeside. 


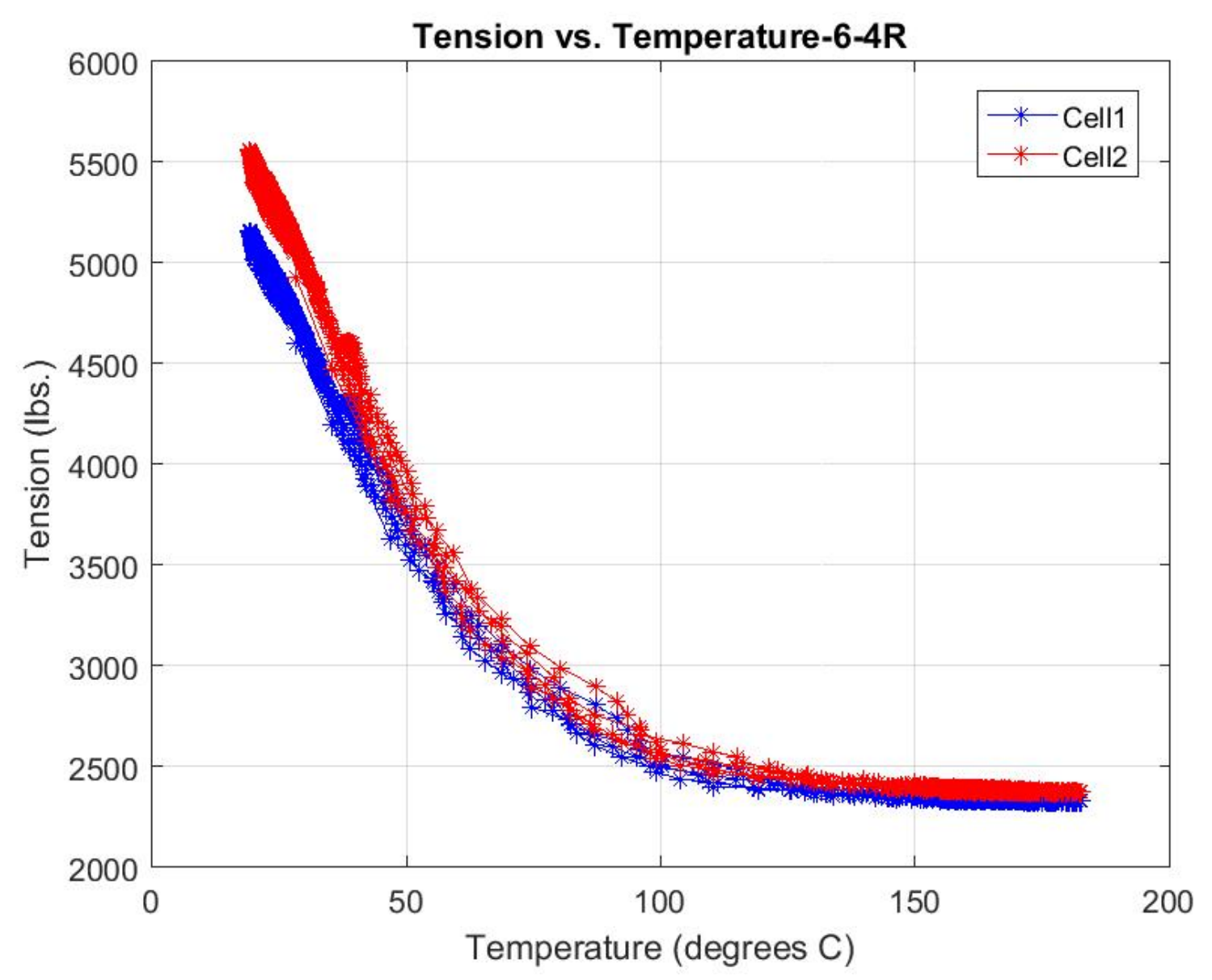

Figure 15. Initial knee point results for thermocouple channel 6 roadside. 


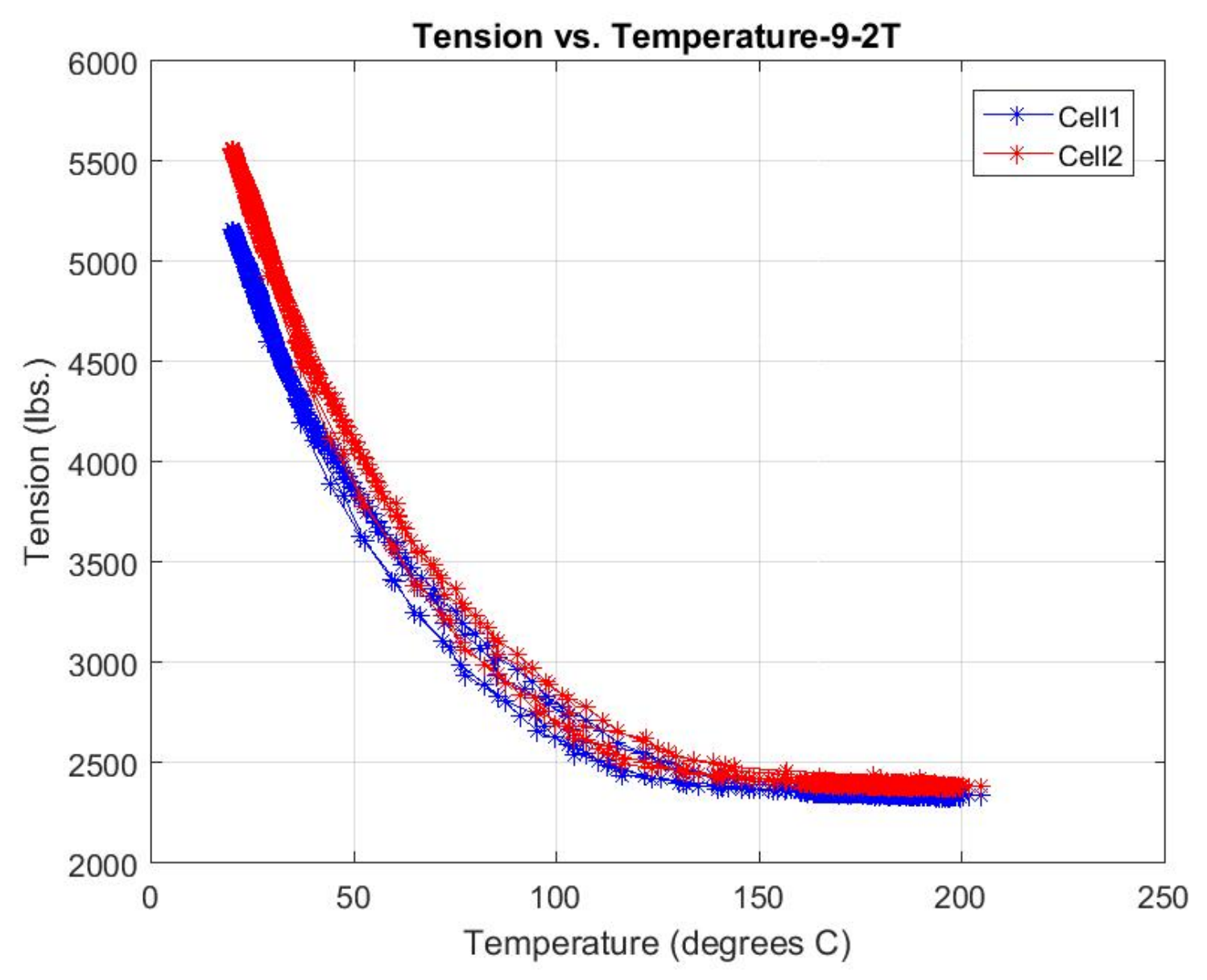

Figure 16. Initial knee point results for thermocouple channel 9 treeside. 


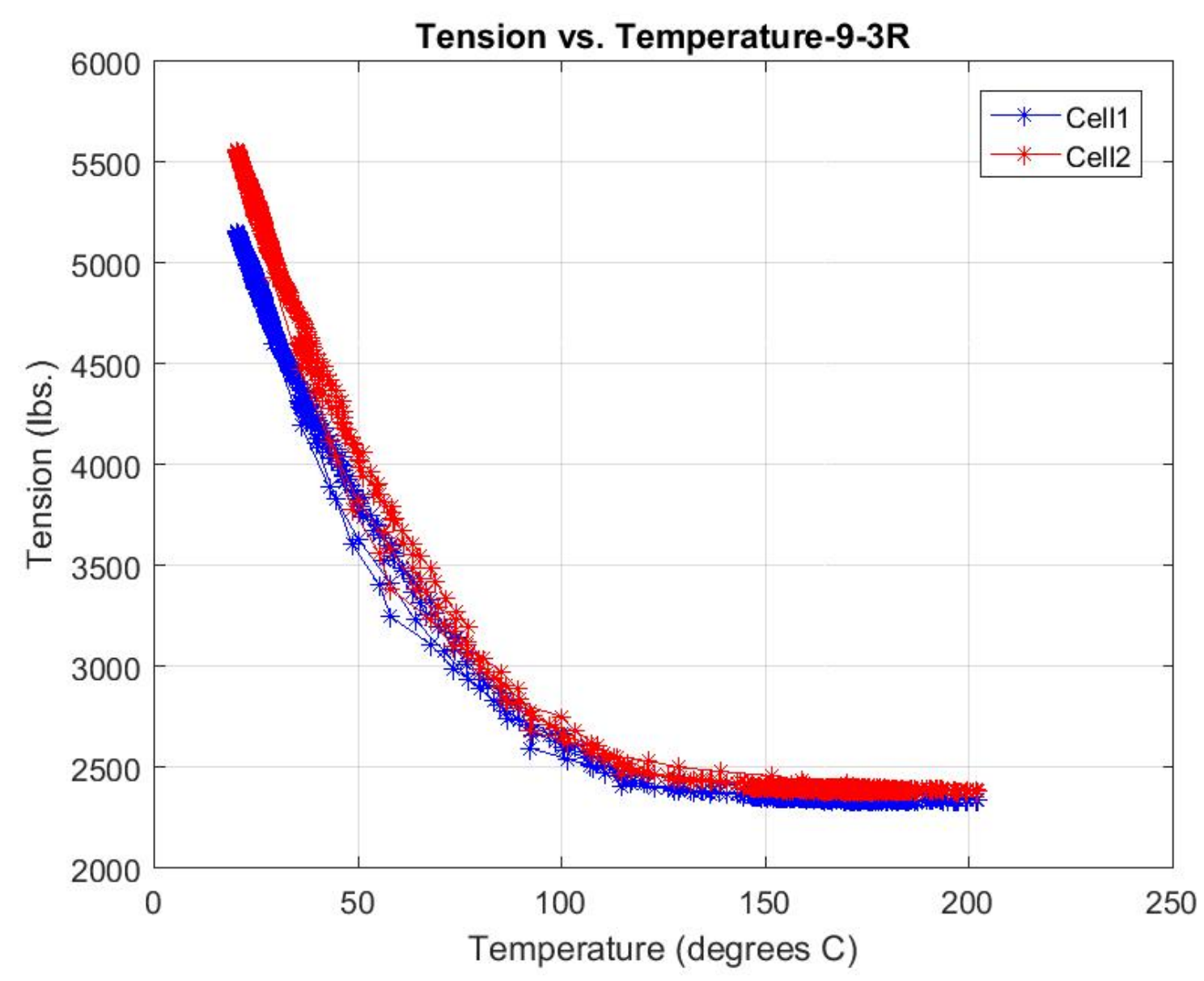

Figure 17. Initial knee point results for thermocouple channel 9 roadside. 


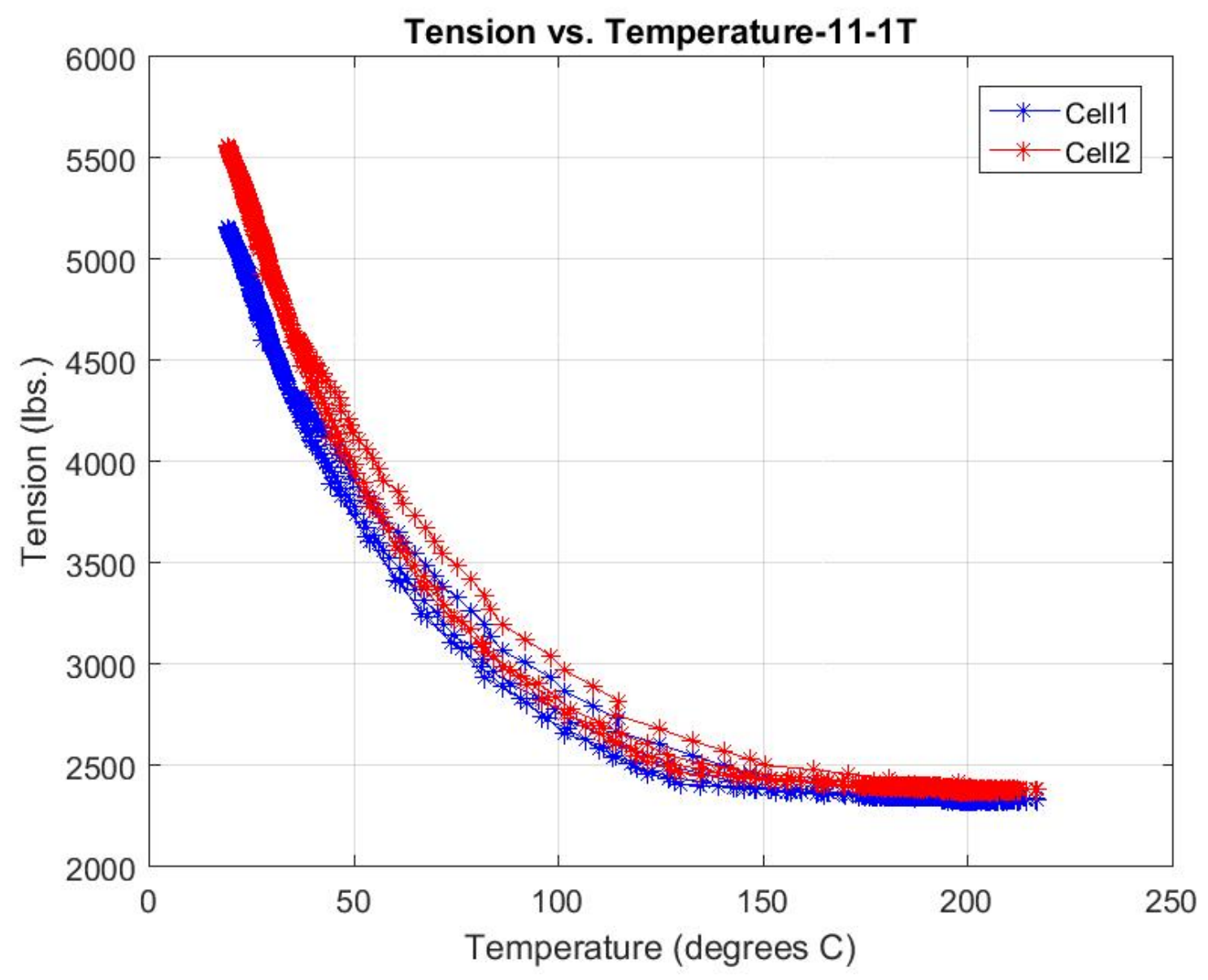

Figure 18. Initial knee point results for thermocouple channel 11 treeside. 


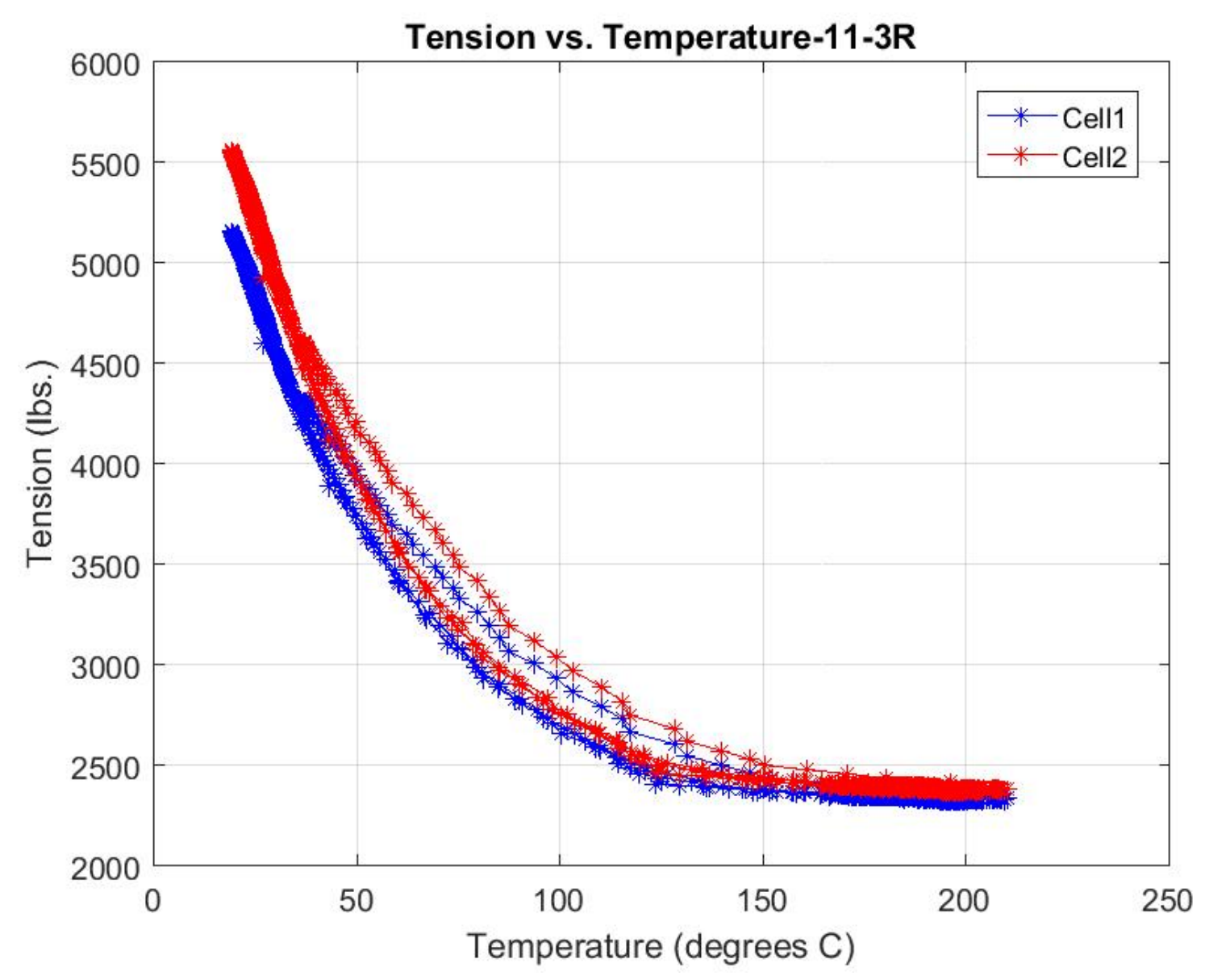

Figure 19. Initial knee point results for thermocouple channel 11 roadside.

\subsection{THERMAL AGING AT RATED CONDUCTOR TEMPERATURE}

Figure 20-25 show results for thermal aging at the rated conductor temperature. 


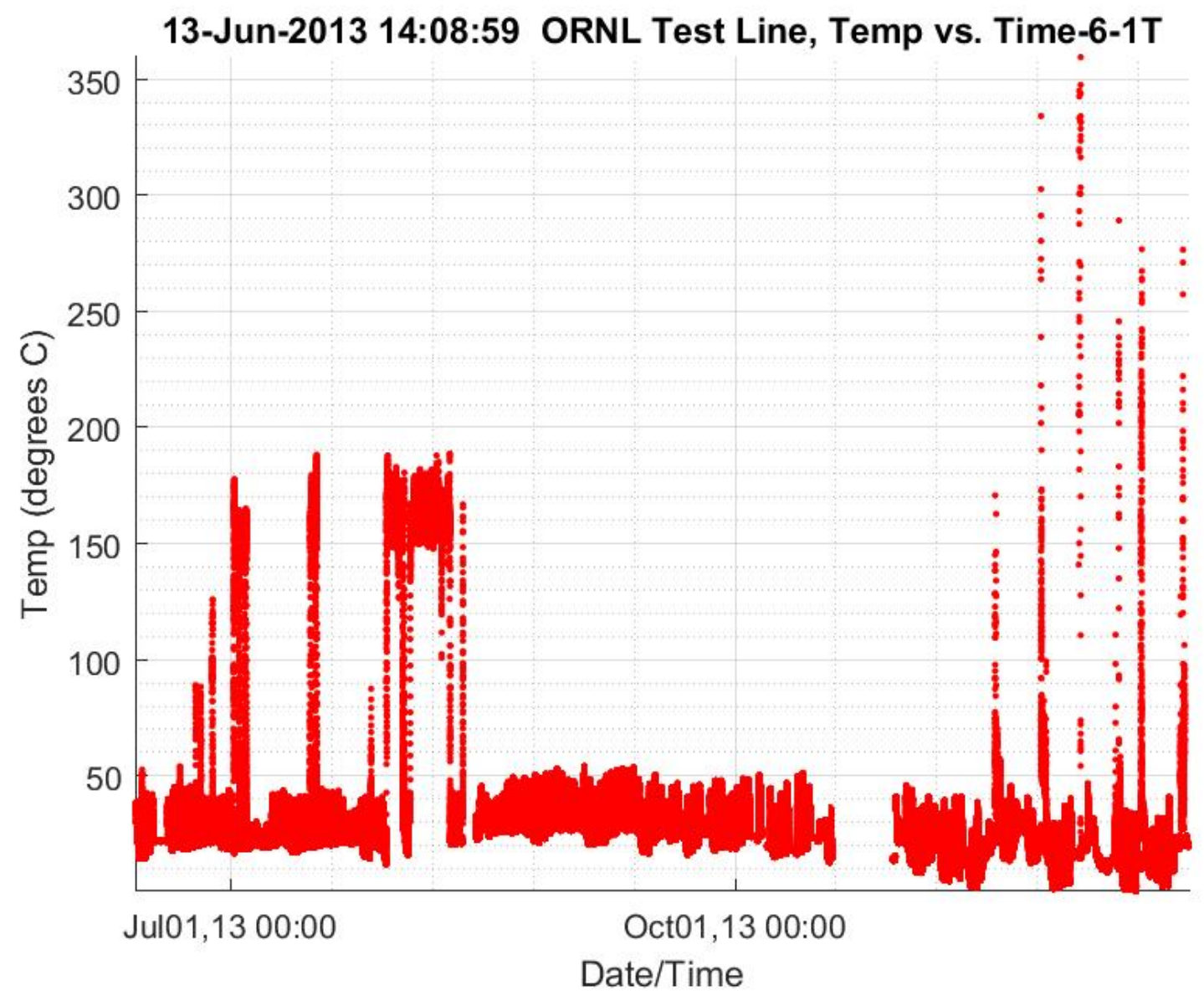

Figure 20. Thermal aging results for thermocouple channel 6 treeside. 


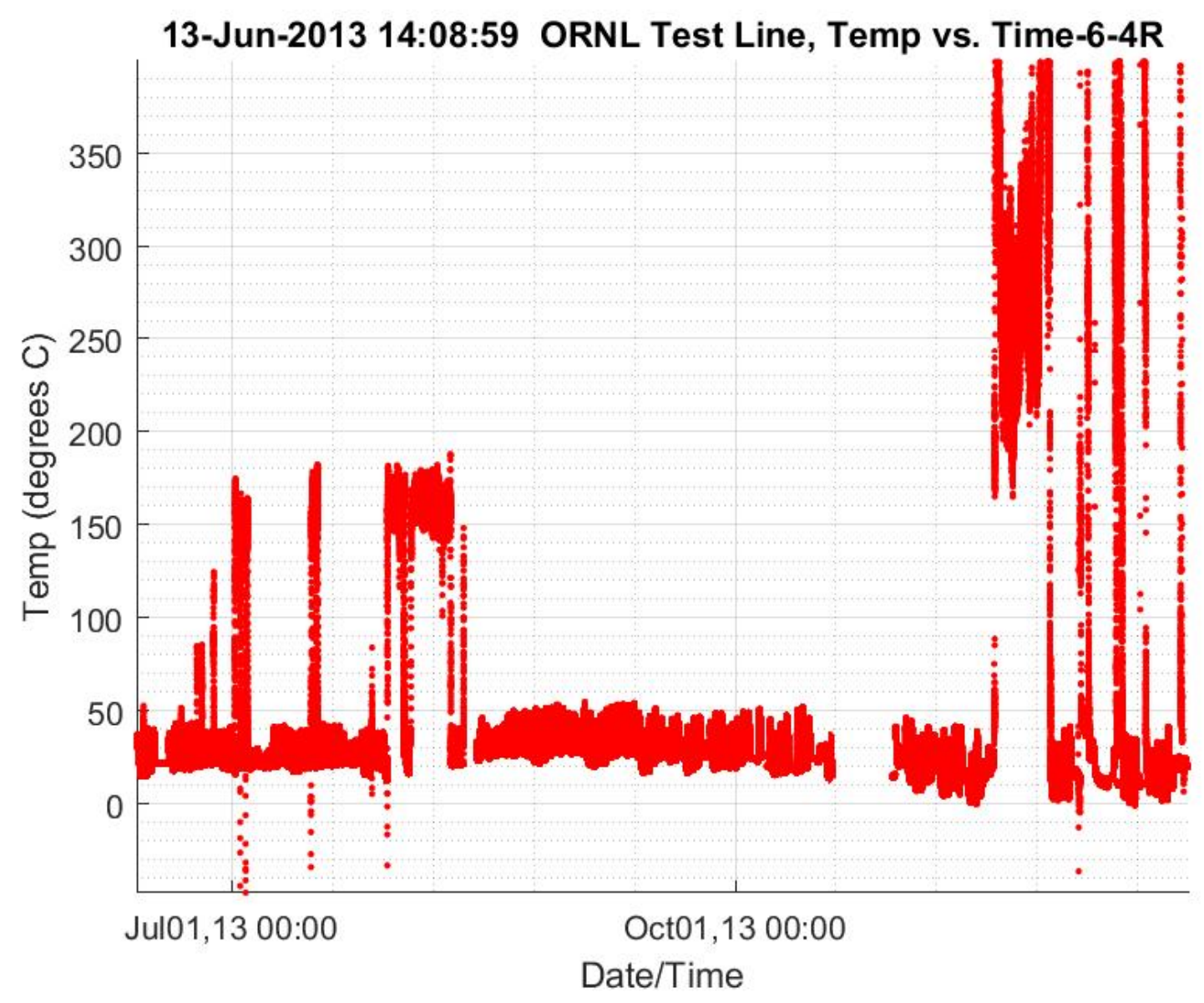

Figure 21. Thermal aging results for thermocouple channel 6 roadside. 


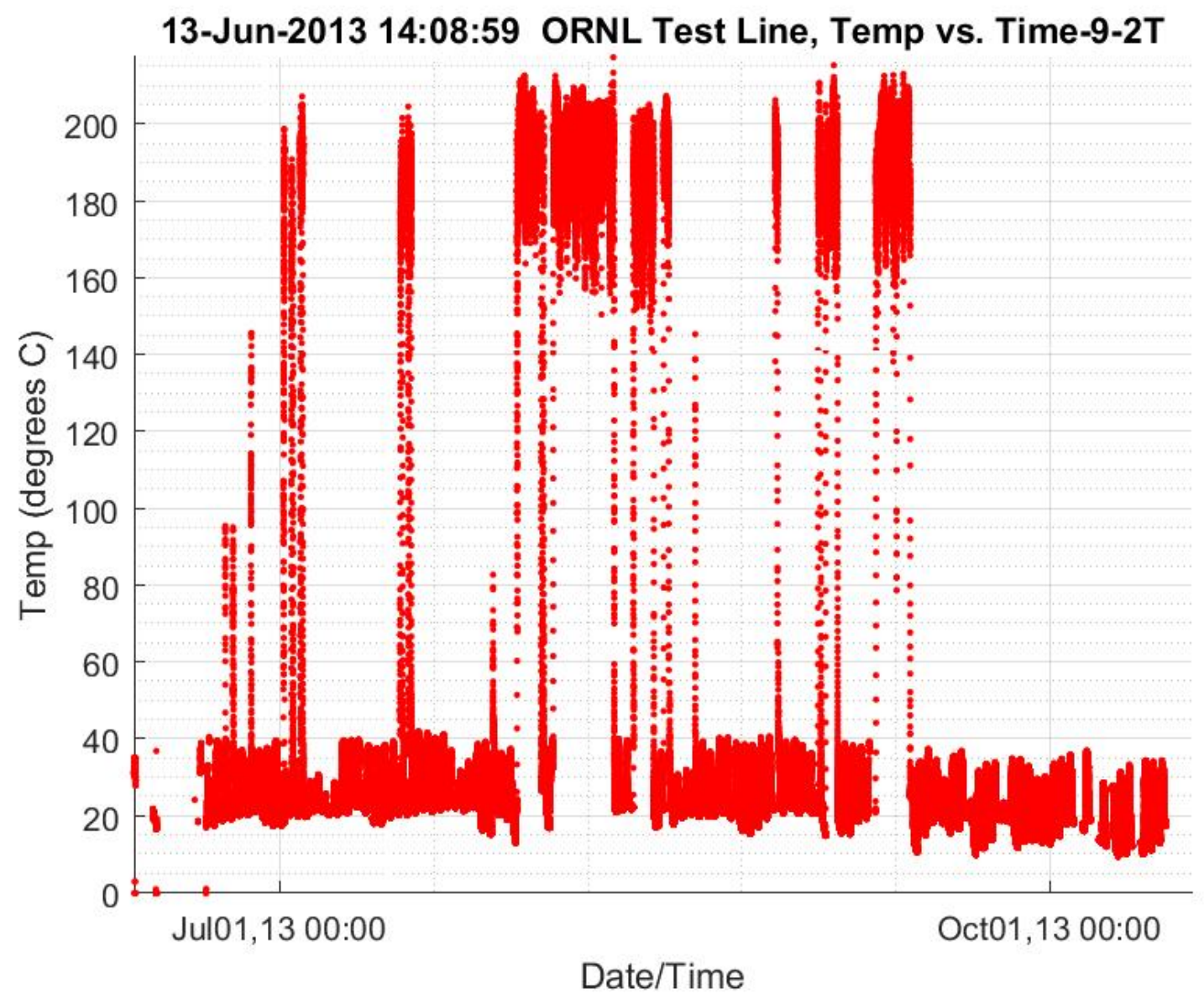

Figure 22. Thermal aging results for thermocouple channel 9 treeside. 


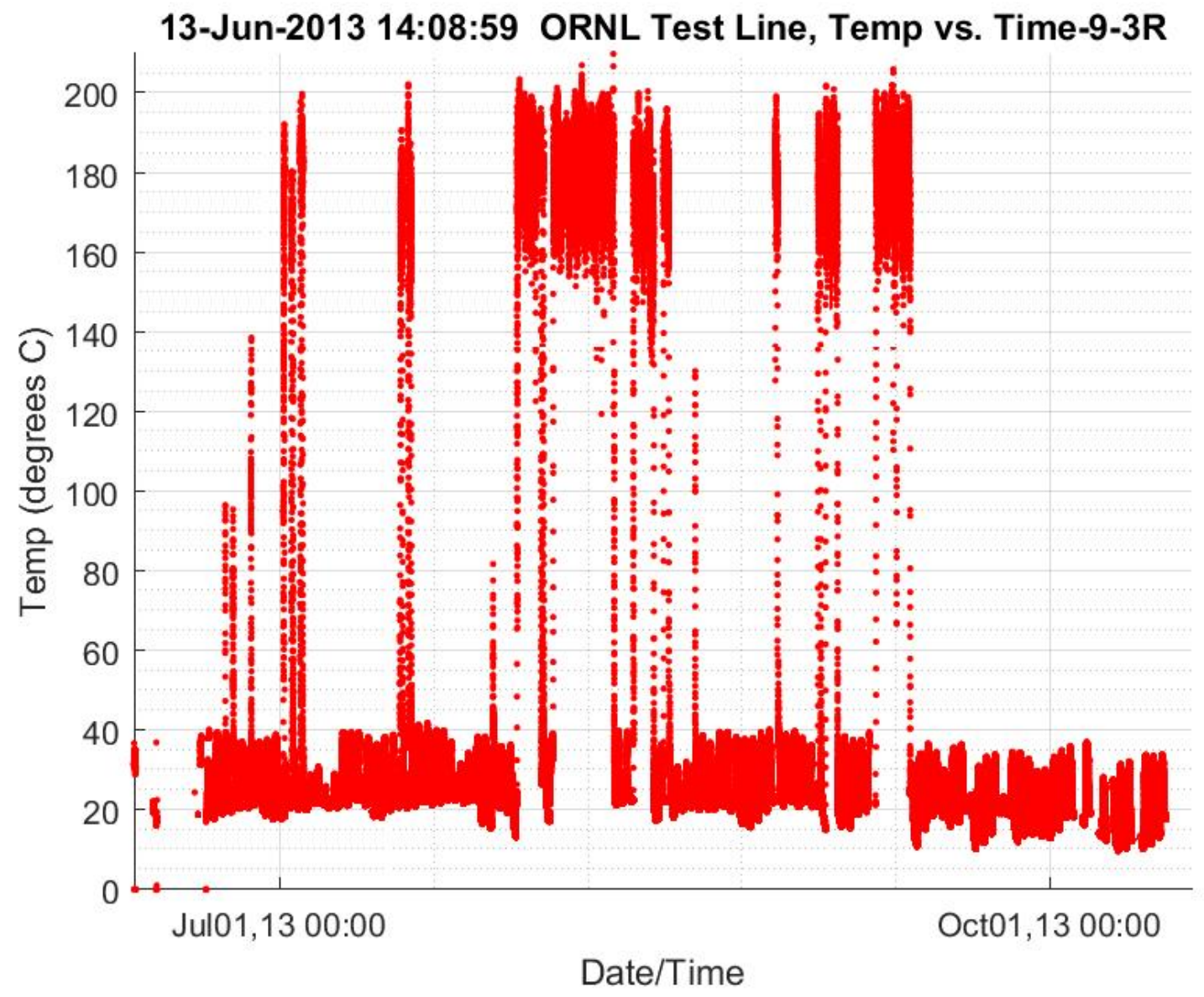

Figure 23. Thermal aging results for thermocouple channel 9 roadside. 


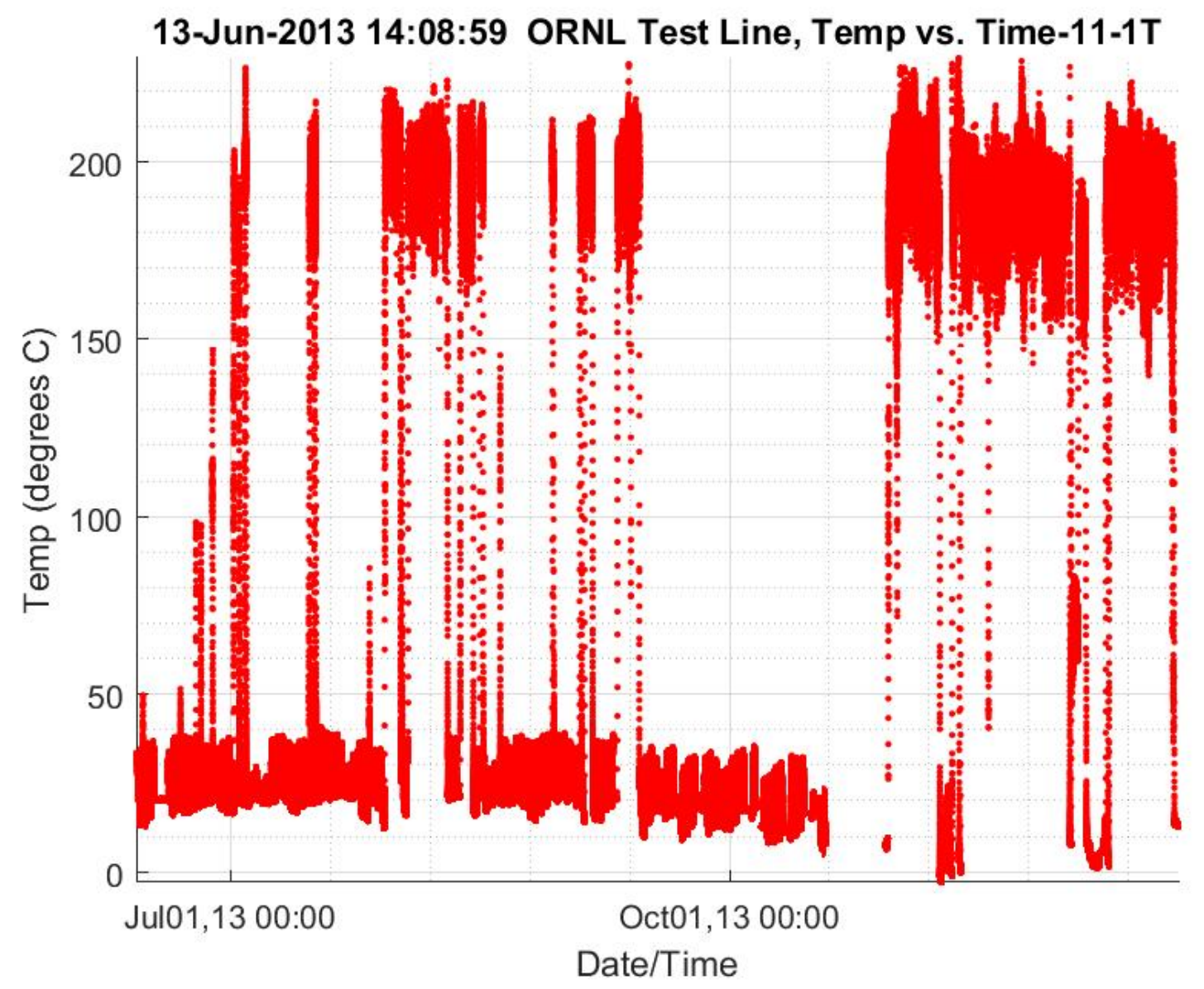

Figure 24. Thermal aging results for thermocouple channel 11 treeside. 


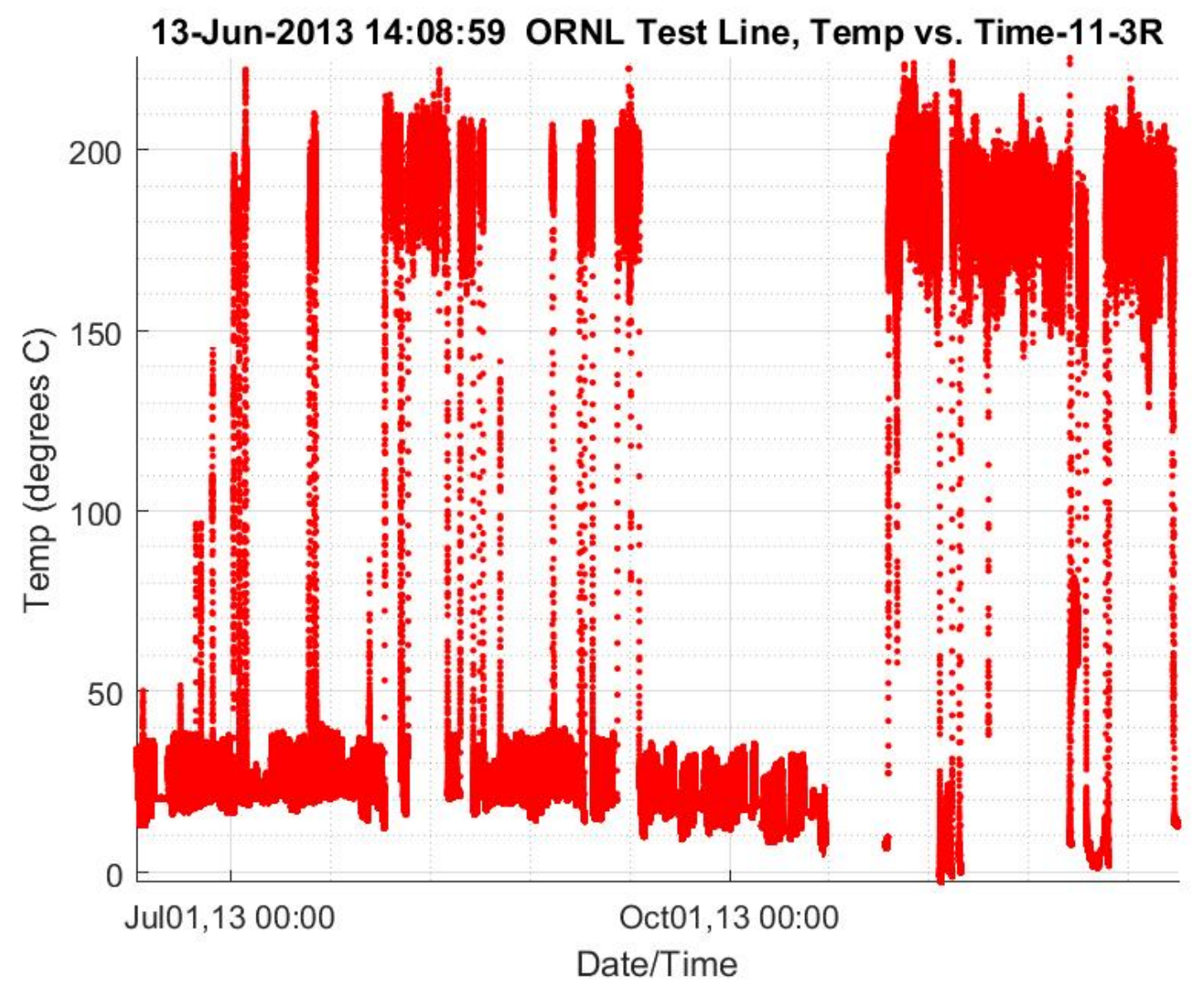

Figure 25. Thermal aging results for thermocouple channel 11 roadside. 


\subsection{THERMAL AGING AT EMERGENCY CONDUCTOR TEMPERATURE}

Figure 26-31 show thermal aging at emergency temperatures.

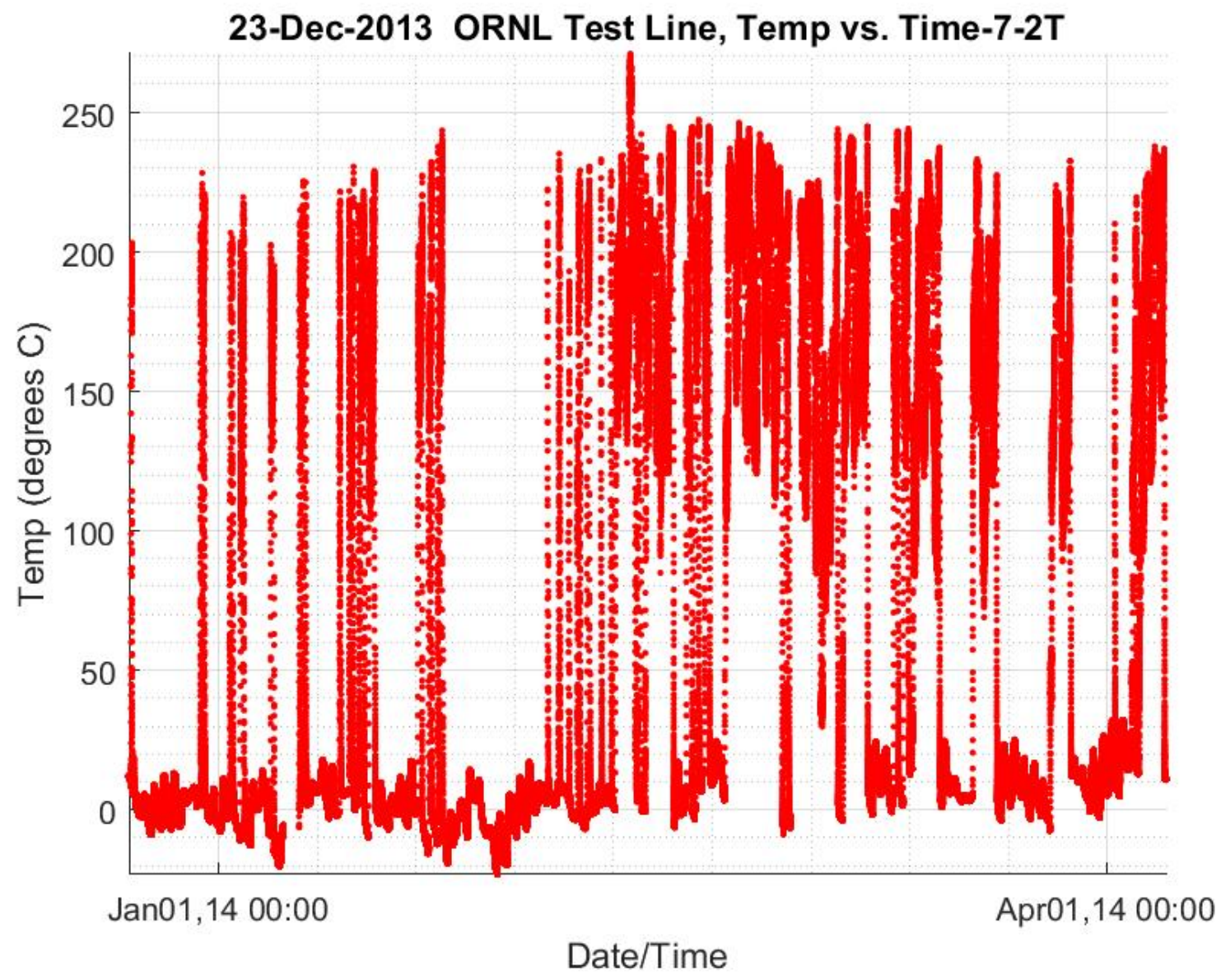

Figure 26. Thermal aging at emergency temperature results for thermocouple channel 7 treeside. 


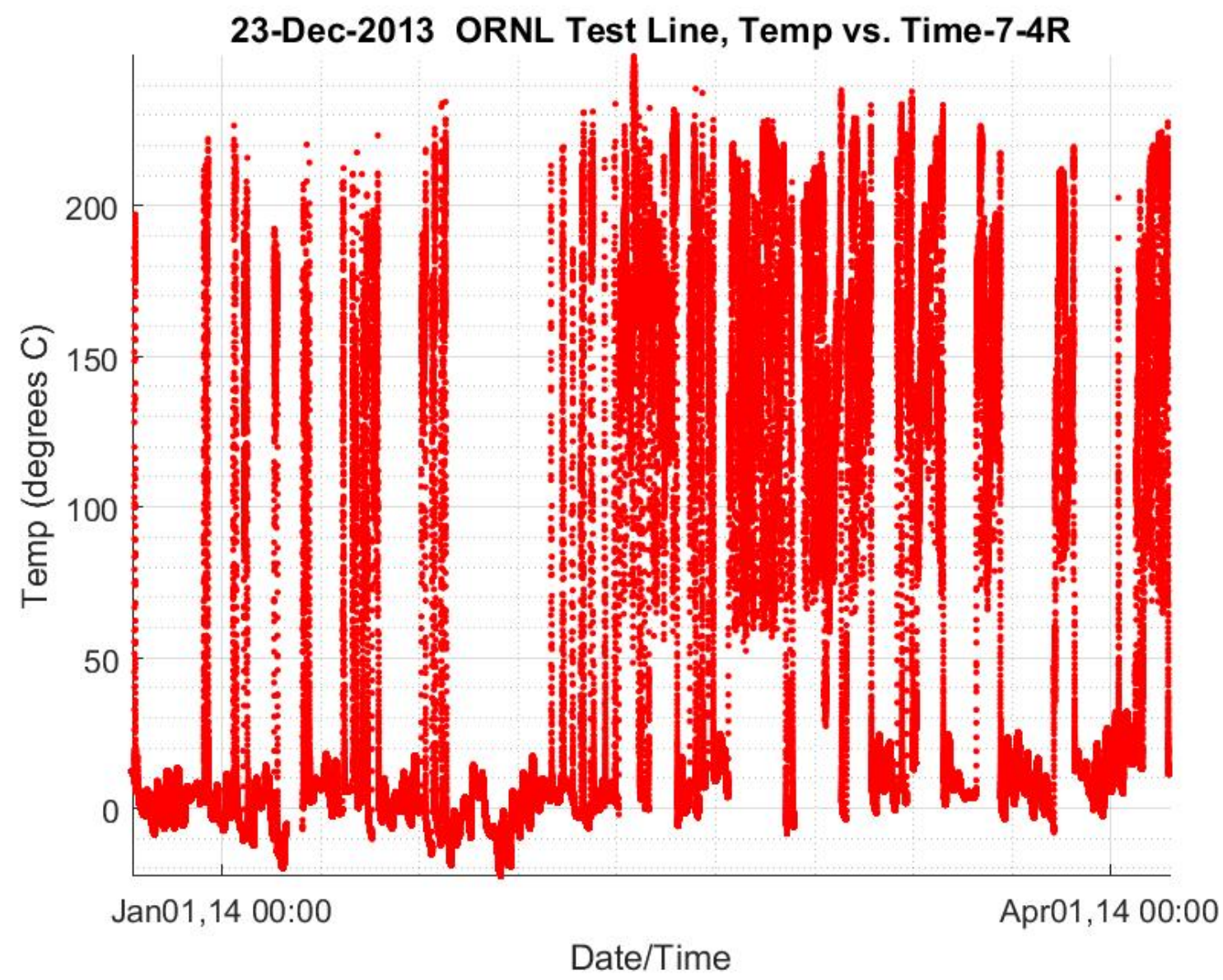

Figure 27. Thermal aging at emergency temperature results for thermocouple channel 7 roadside. 


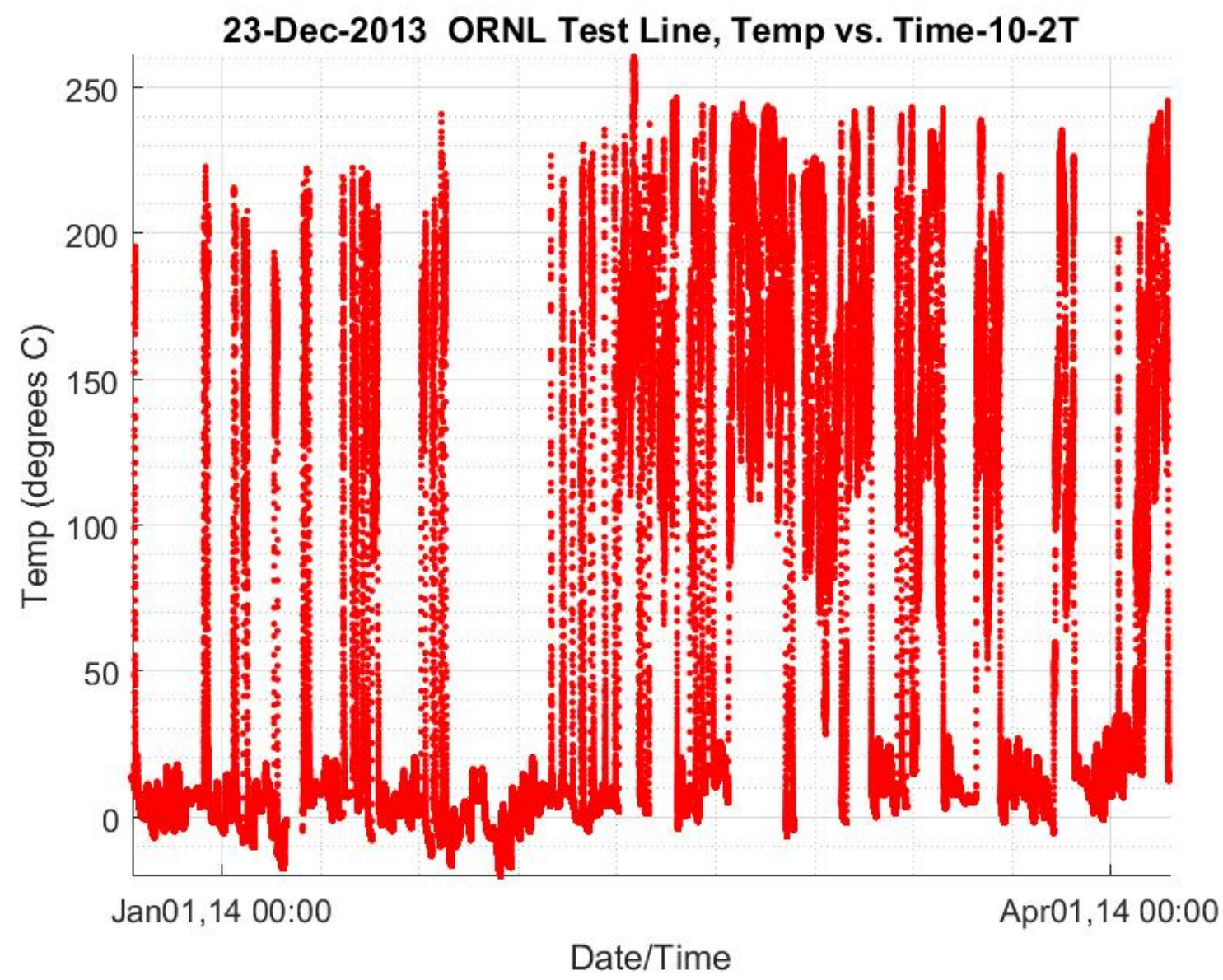

Figure 28. Thermal aging at emergency temperature results for thermocouple channel 10 treeside. 


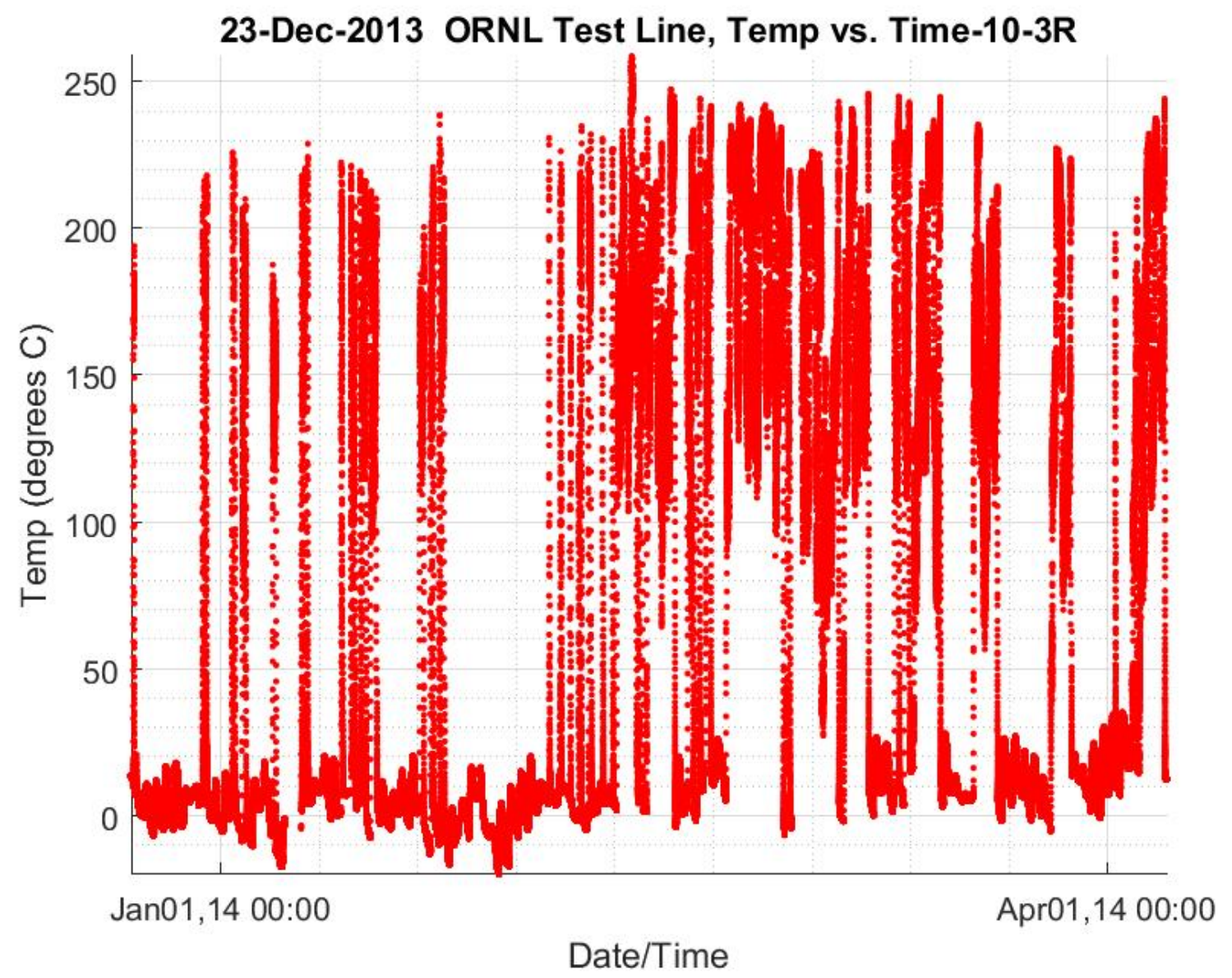

Figure 29. Thermal aging at emergency temperature results for thermocouple channel 10 roadside. 


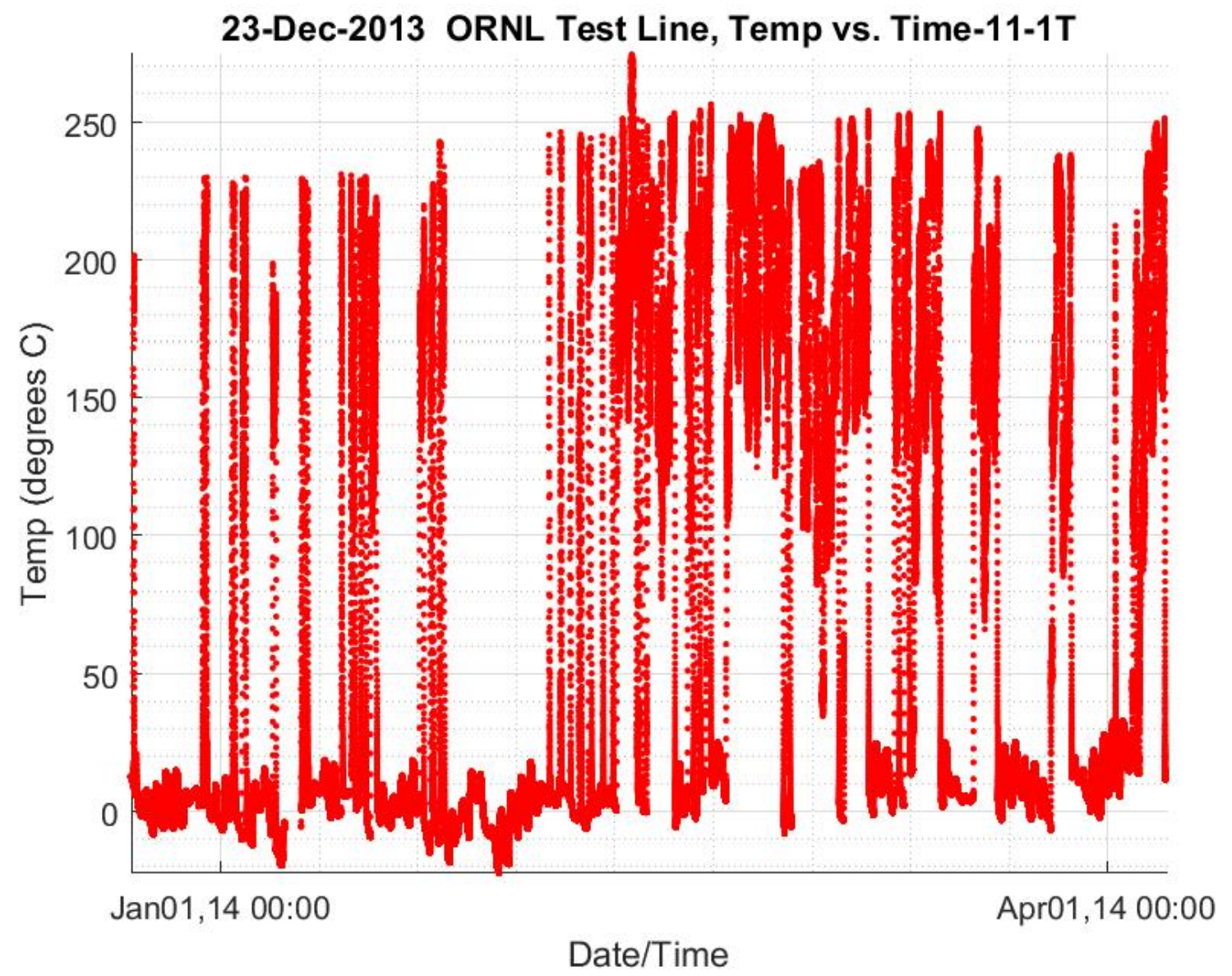

Figure 30. Thermal aging at emergency temperature results for thermocouple channel 11 treeside. 


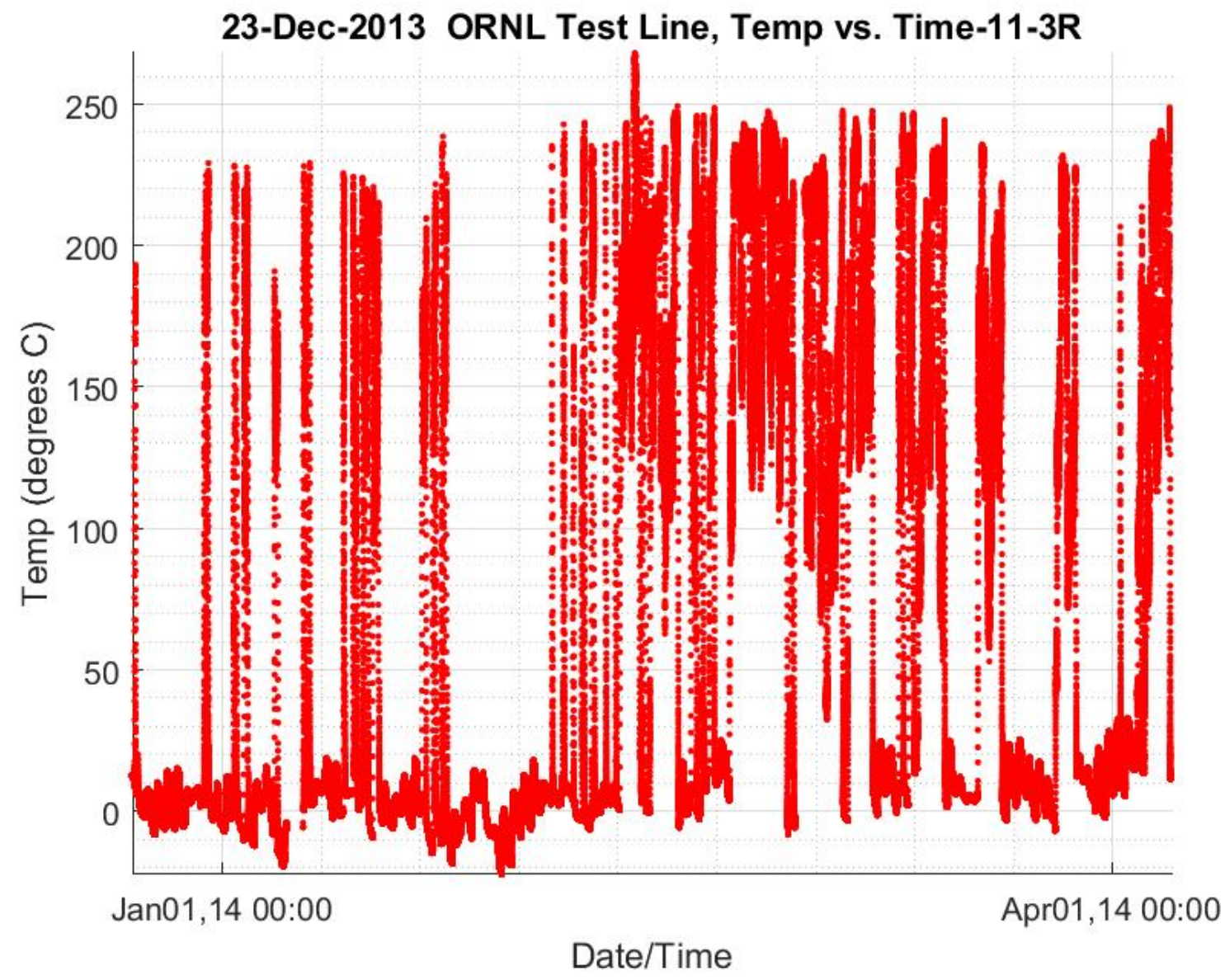

Figure 31. Thermal aging at emergency temperature results for thermocouple channel 11 roadside. 


\subsection{EXTREME COLD EVENT}

In addition to the planned testing of the Southwire $\mathrm{C} 7$ conductor, there was a unique extreme cold event when a polar vortex dropped the Oak Ridge temperature significantly below the NESC "Medium" requirement and the conductor made the expected deviation from the original line design (Figure 32).

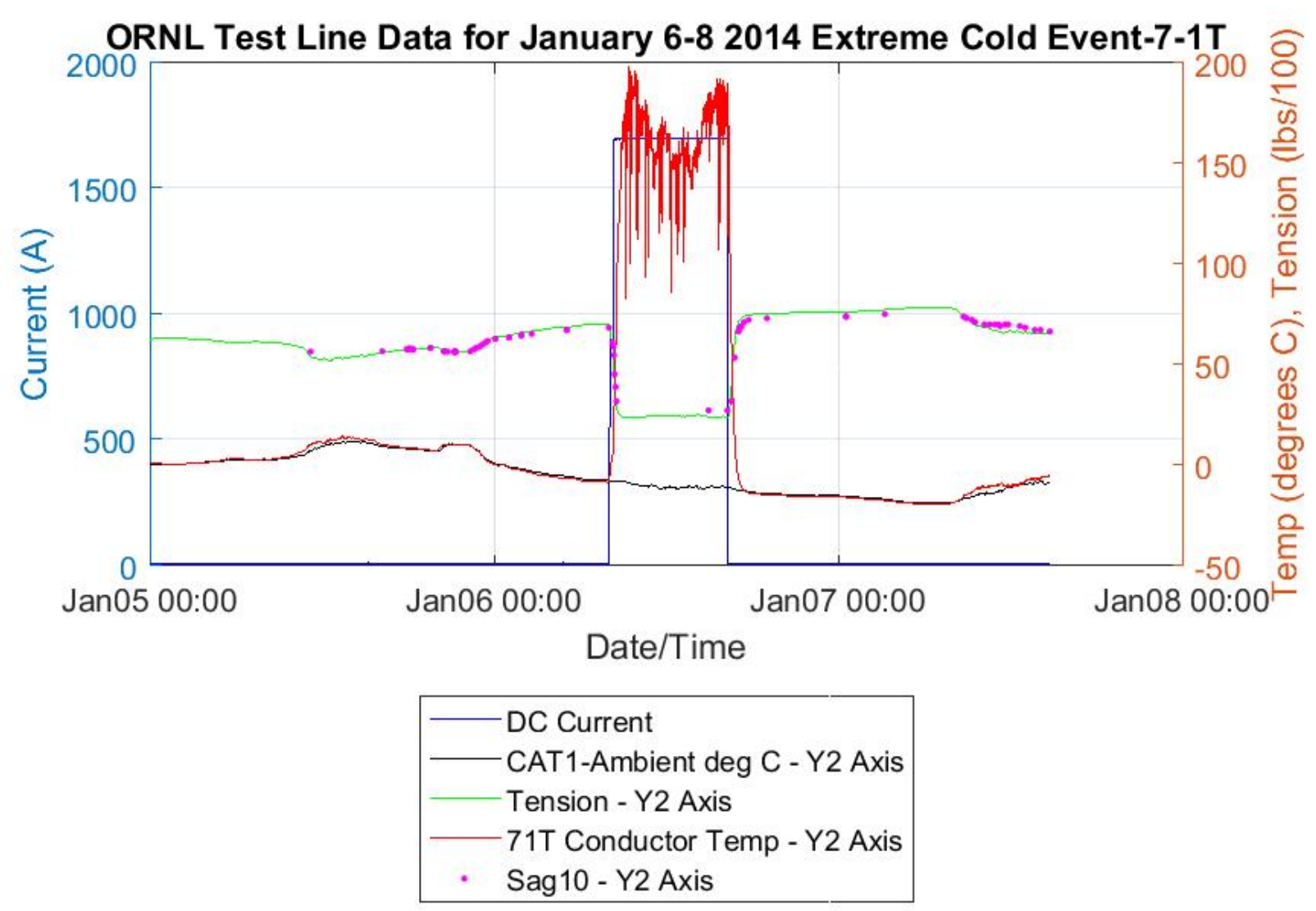

Figure 32. Conductor temperature, Sag10, and current during extreme cold event. 


\subsection{ICE LOADING EVENT}

On January 28-31,there was an ice loading event that exceeded NESC Medium; during this time the conductor made a deviation from the design tables, which assume only the NESC loads. Figure 33-36 show how the conductor responded to the ice loading.

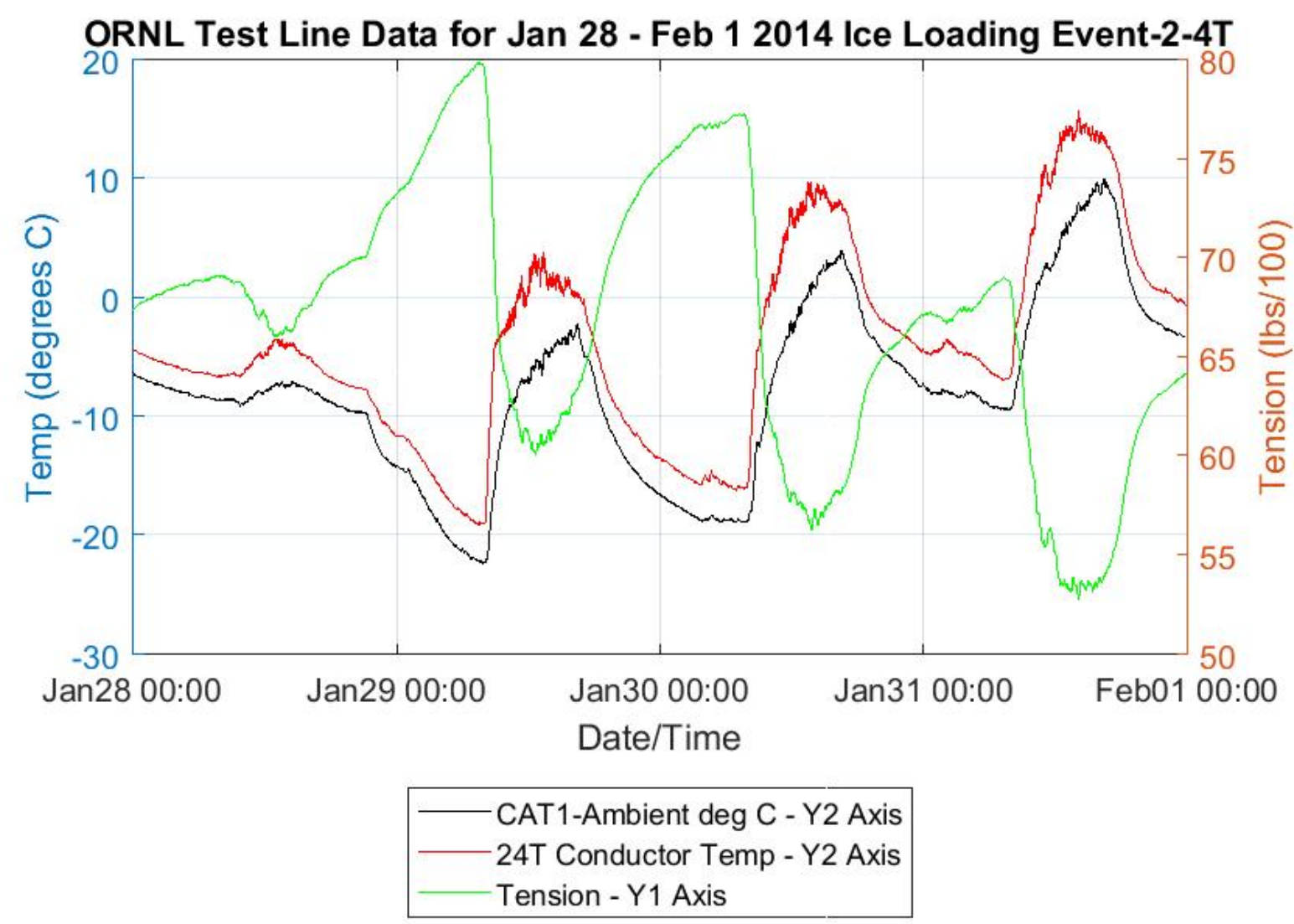

Figure 33. Conductor temperature at channel 2 treeside, ambient temperature and tension. 


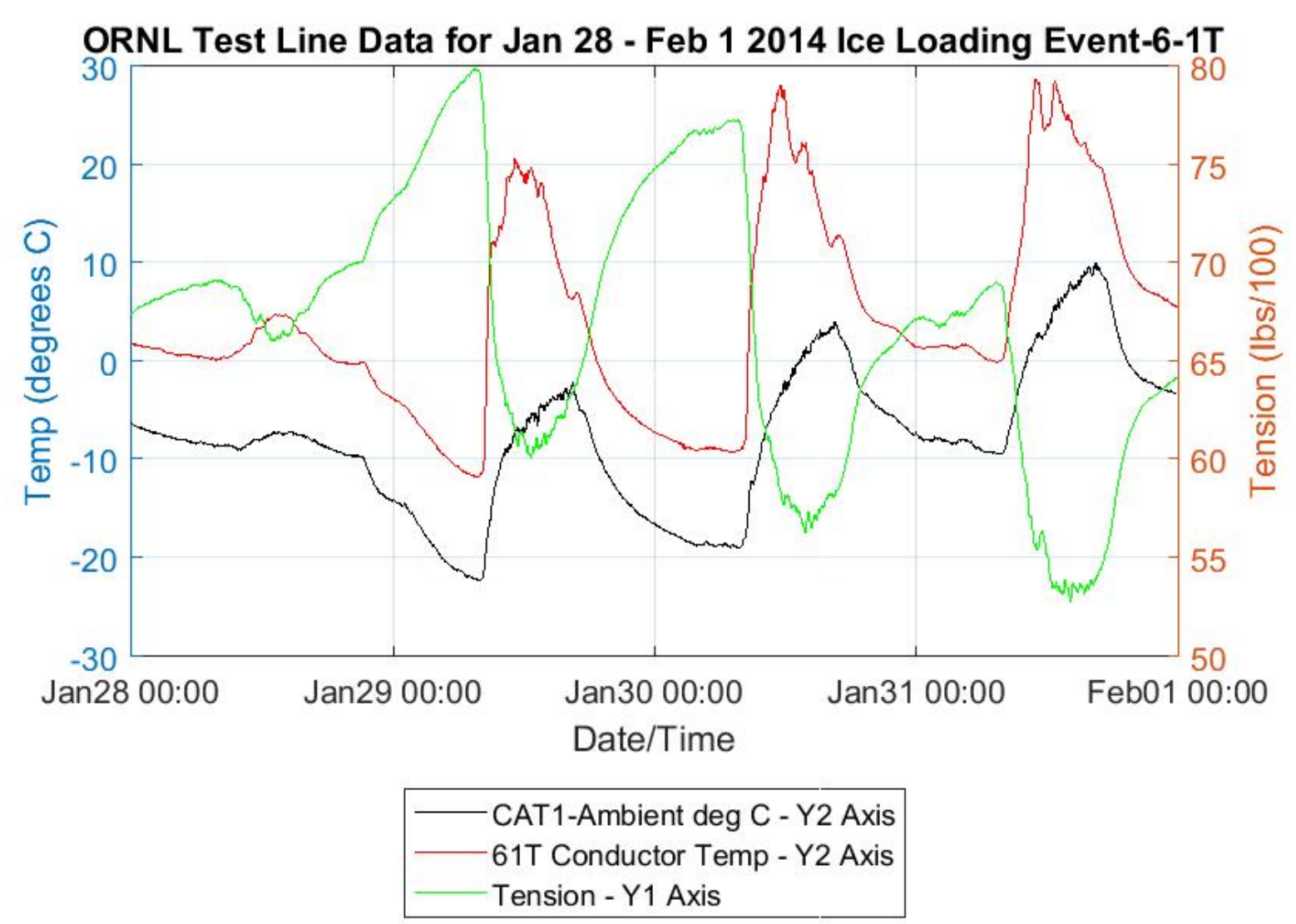

Figure 34. Conductor temperature at channel 6 treeside, ambient temperature and tension. 


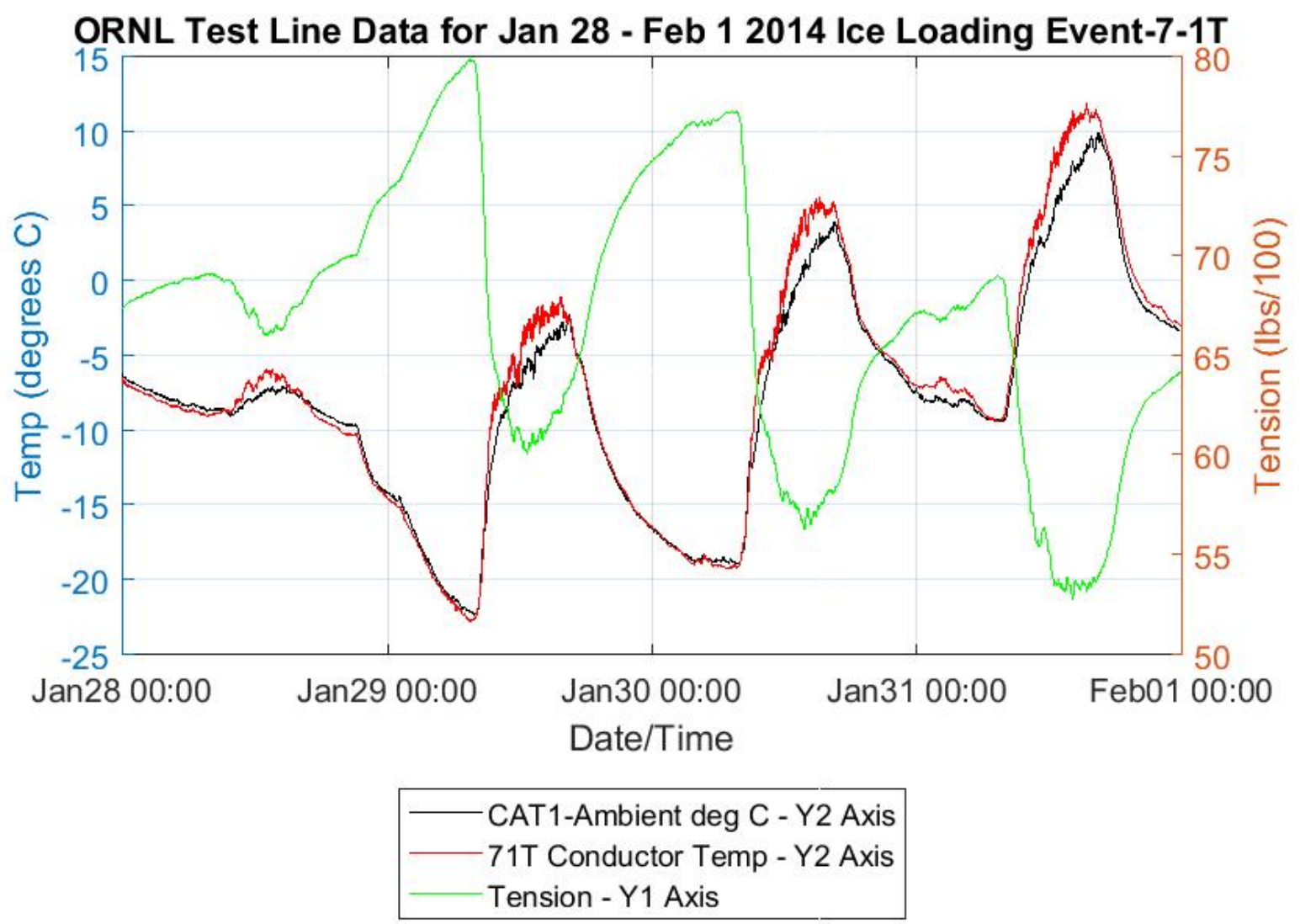

Figure 35. Conductor temperature at channel 7 treeside, ambient temperature and tension. 


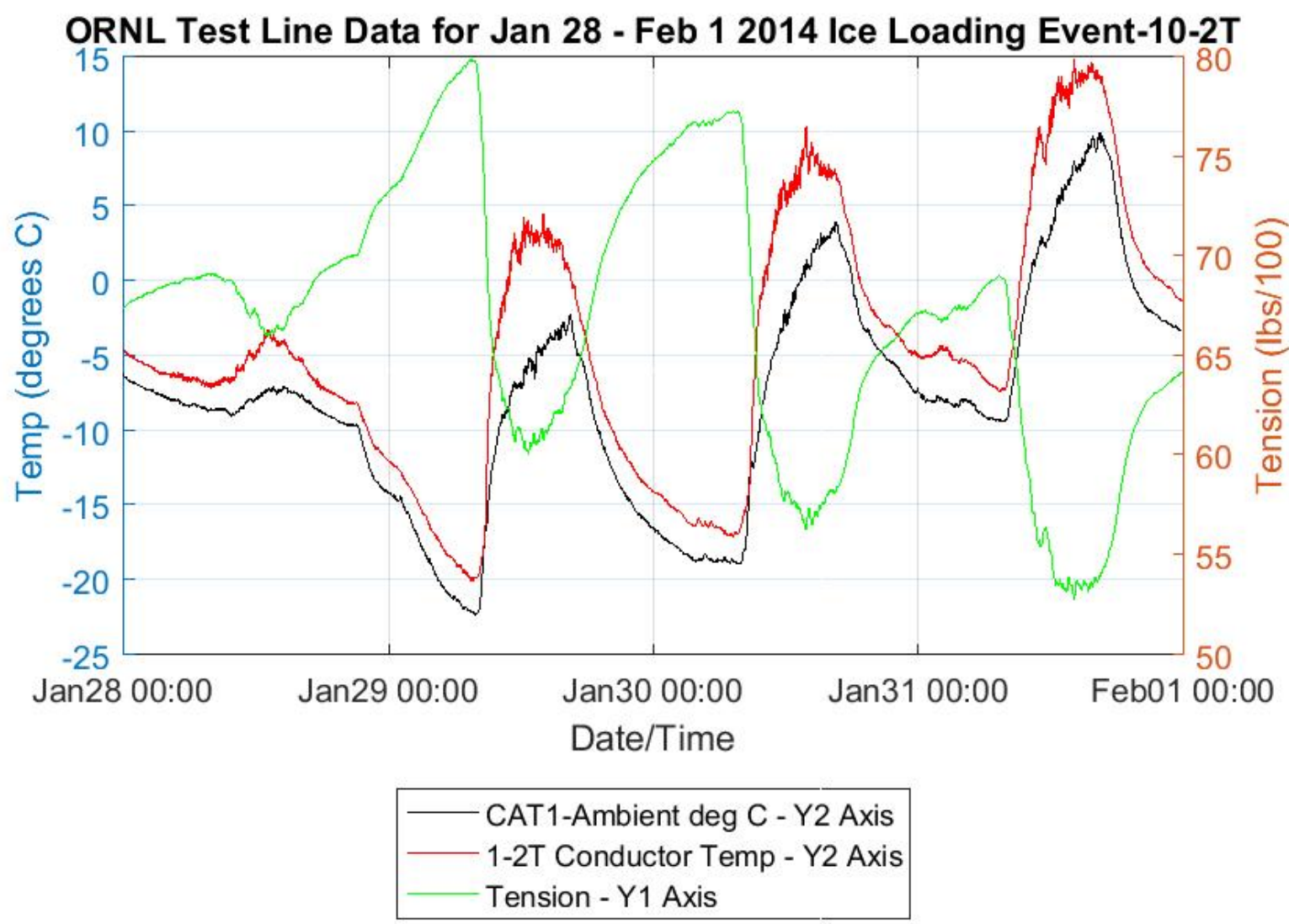

Figure 36. Conductor temperature at channel 10 treeside, ambient temperature and tension.

\subsection{AGED KNEE POINT}

During the aged knee point testing, at the end of the testing period, the knee point was shown to have moved from 100 to $75^{\circ} \mathrm{C}$ (Figure $37-42$ ). 


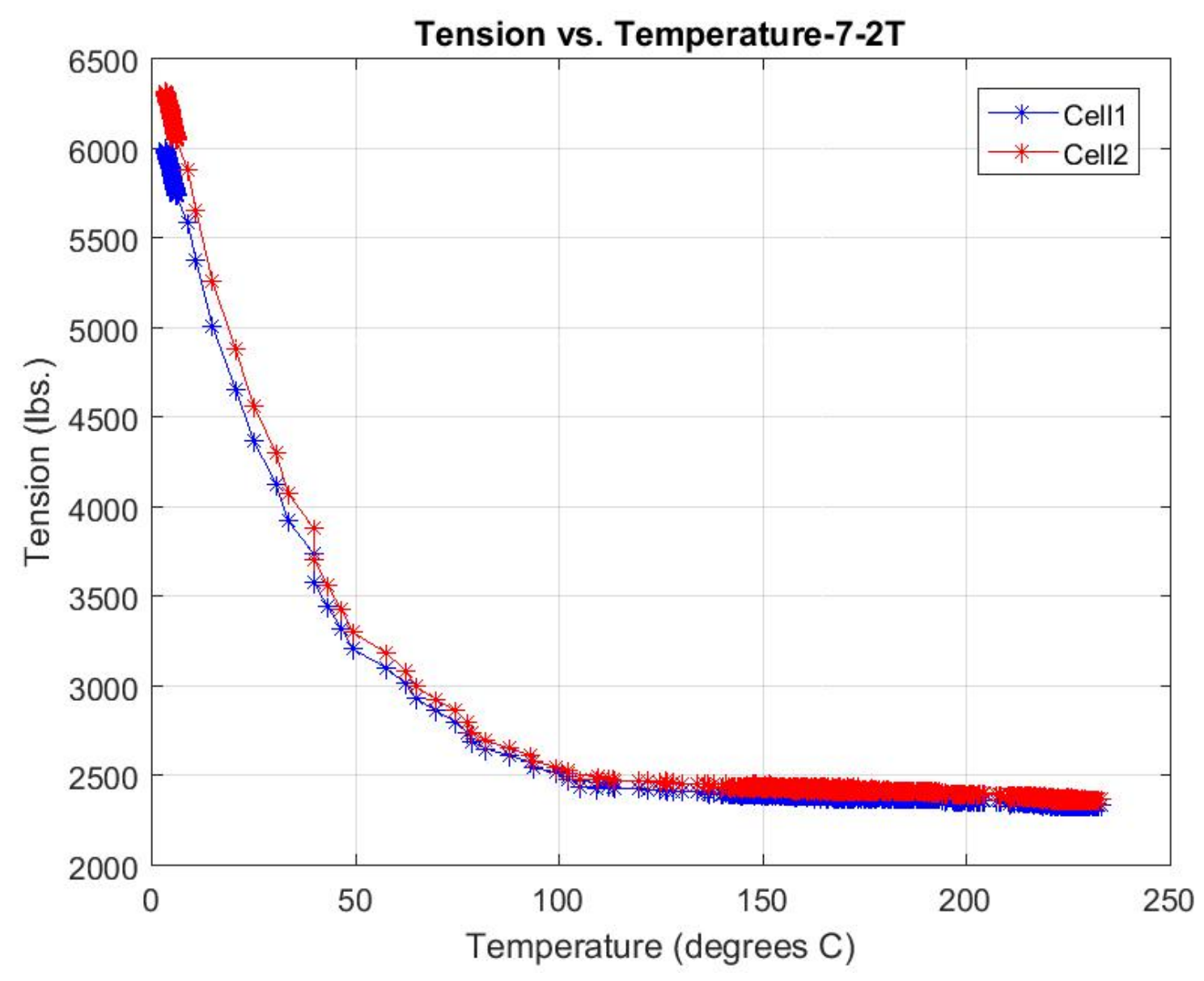

Figure 37. Knee point results at end of testing plotted against thermocouple channel 7 treeside. 


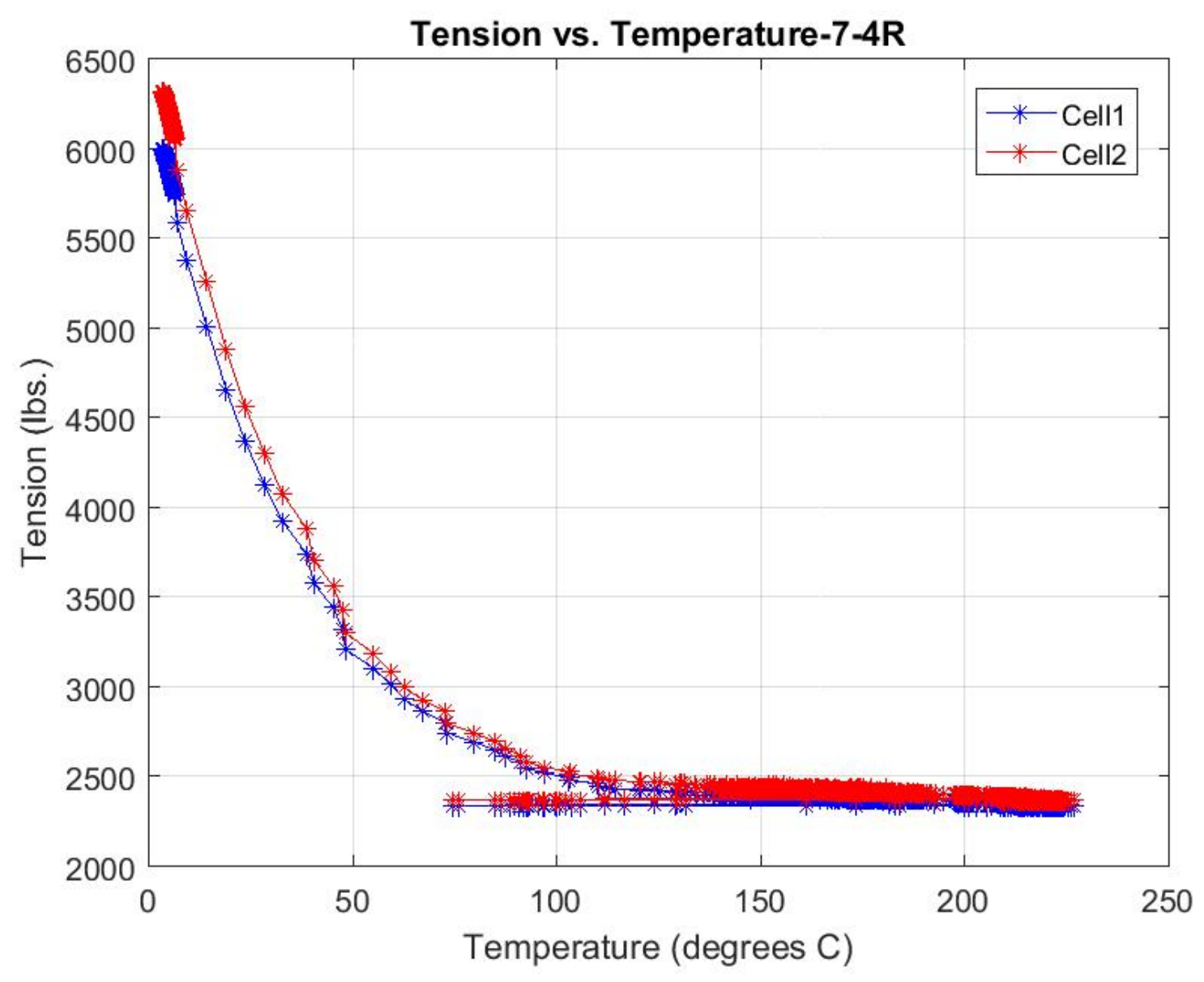

Figure 38. Knee point results at end of testing plotted against thermocouple channel 7 roadside. 


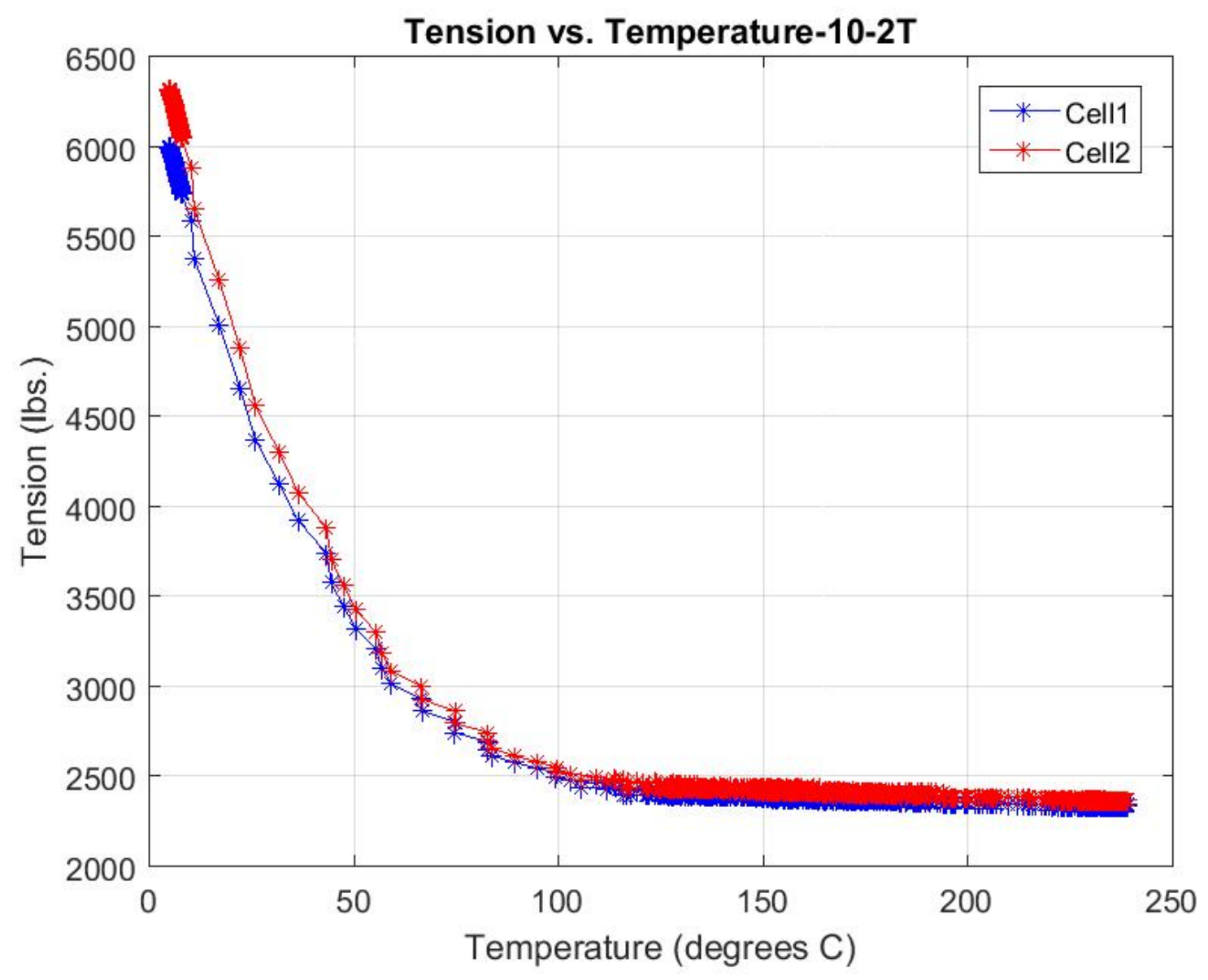

Figure 39. Knee point results at end of testing plotted against thermocouple channel 10 treeside. 


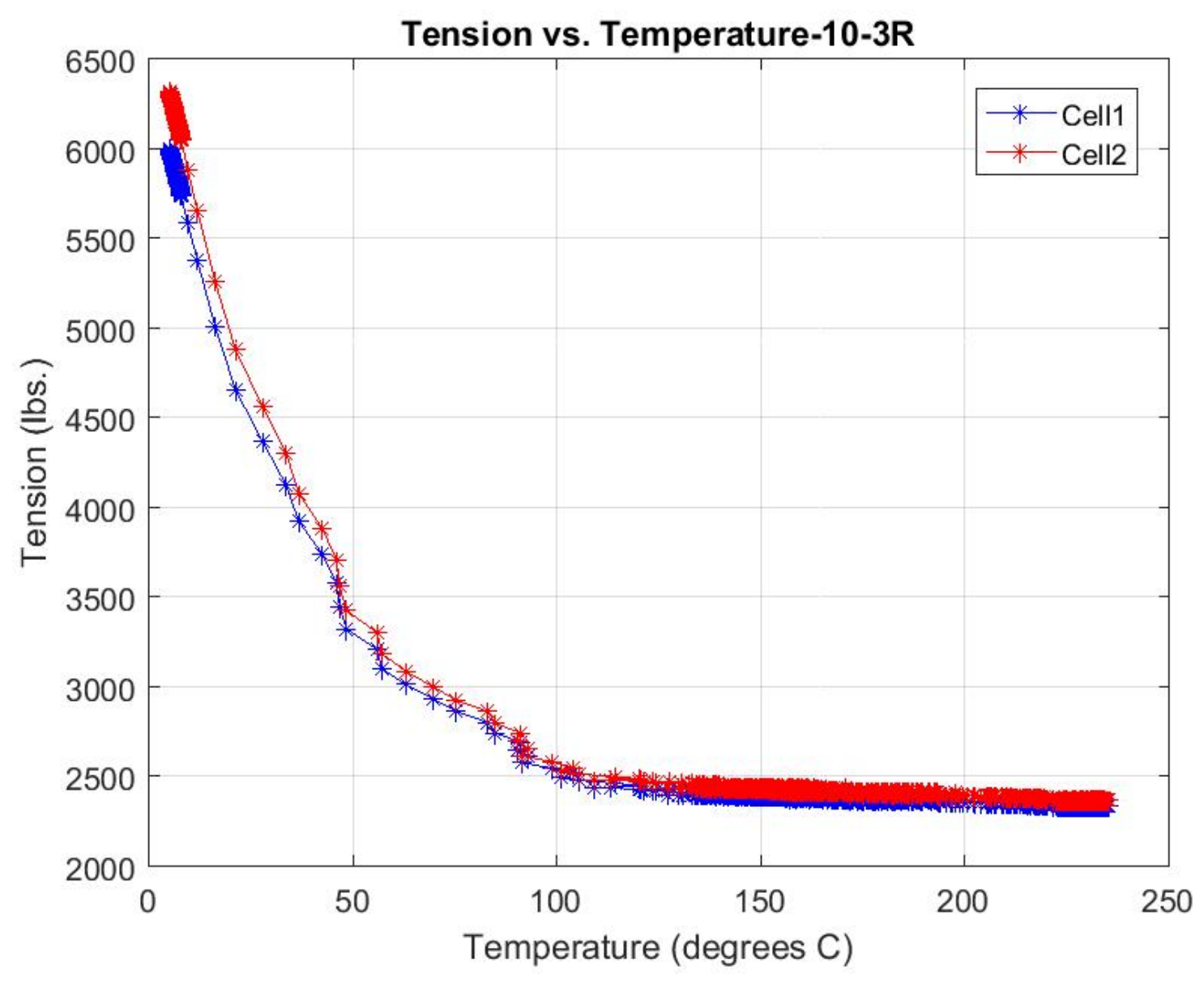

Figure 40. Knee point results at end of testing plotted against thermocouple channel 10 roadside. 


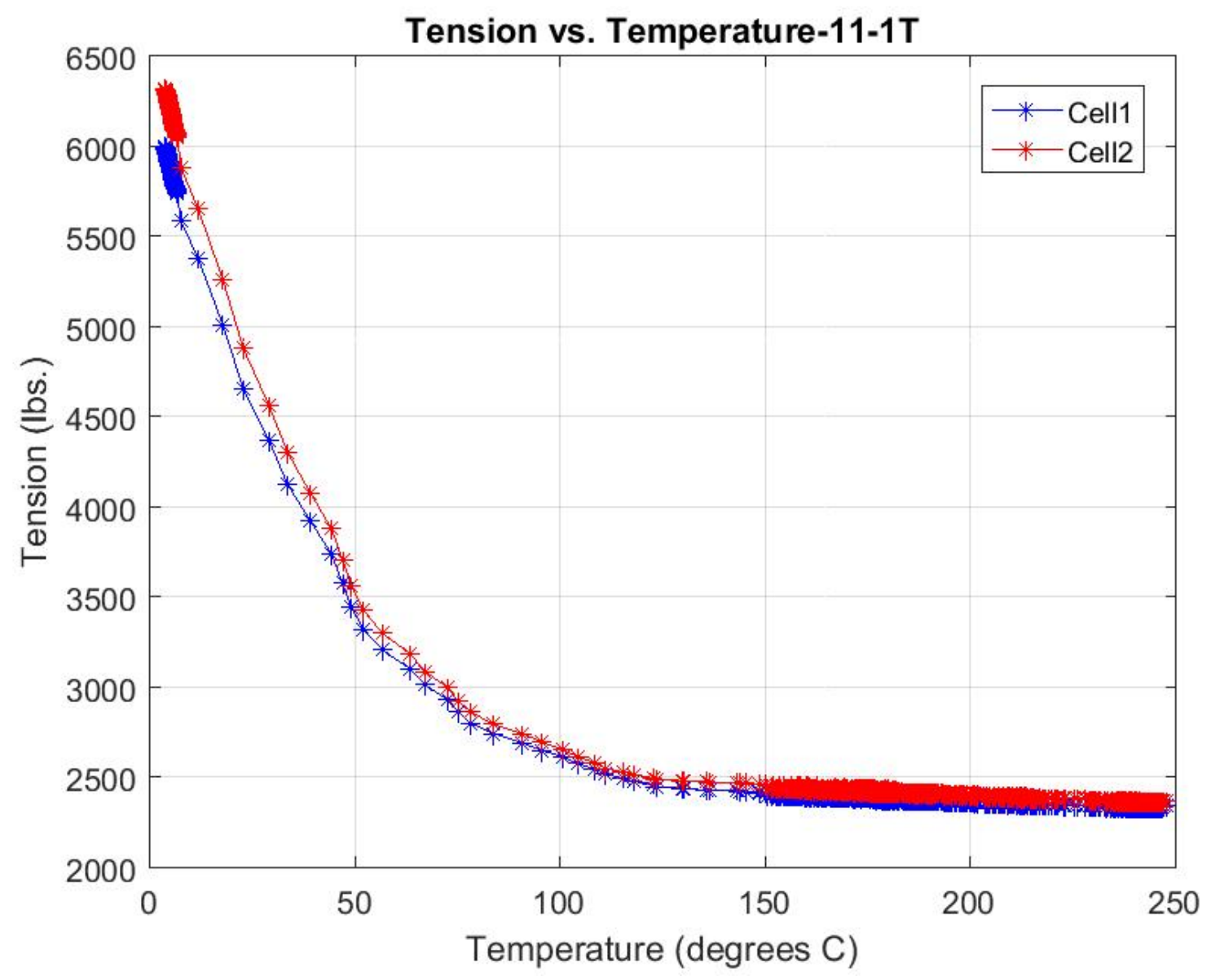

Figure 41. Knee point results at end of testing plotted against thermocouple channel 11 treeside. 


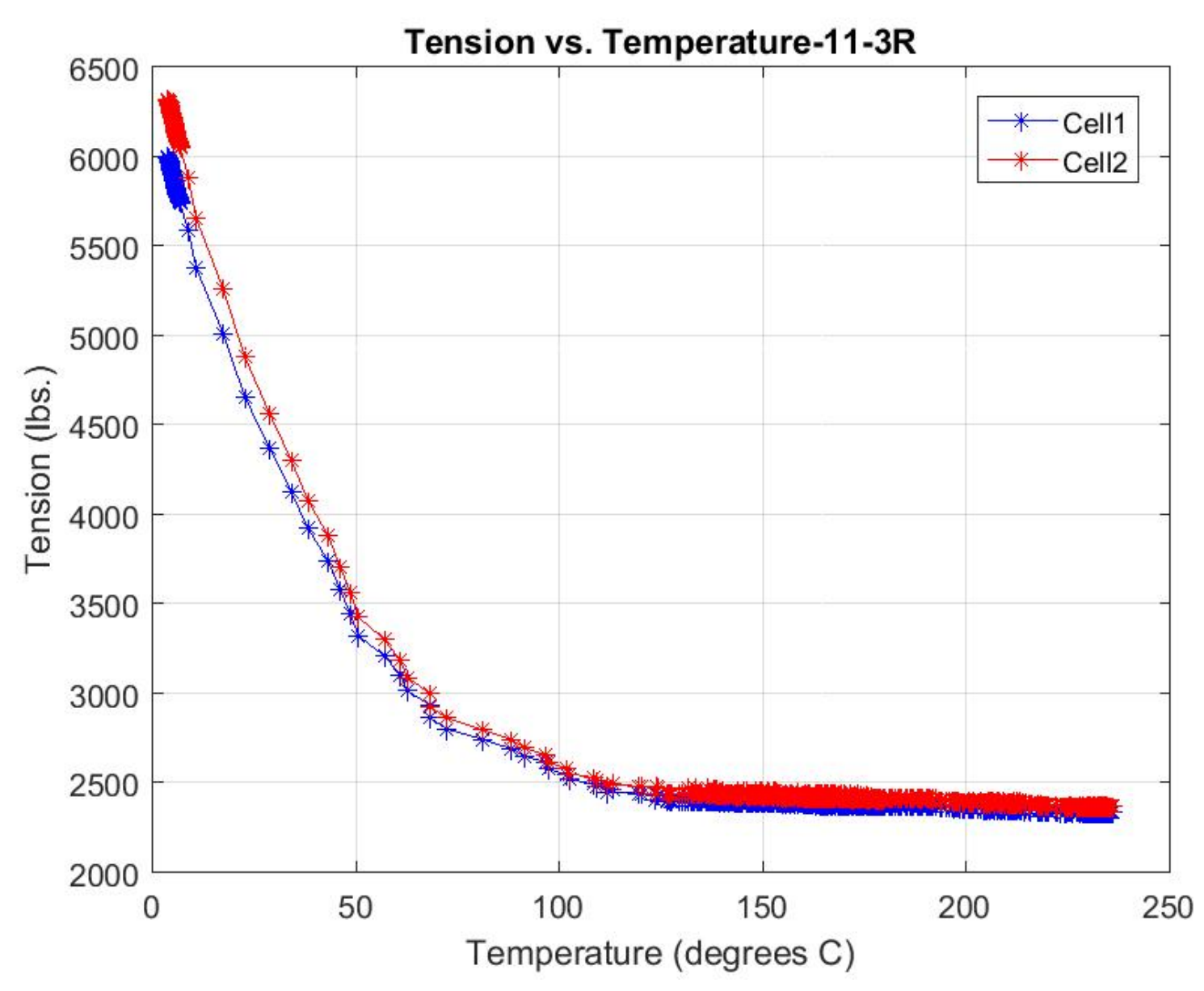

Figure 42. Knee point results at end of testing plotted against thermocouple channel 11 roadside.

\section{SUMMARY OF OBSERVATIONS}

The Southwire C7 conductor was tested at the ORNL PCAT facility, undergoing testing that included thermal aging at rated conductor temperature, emergency temperature, and emergency overload conditions. During this time, the conductor behaved as expected (Figure 43 and Figure 44). 


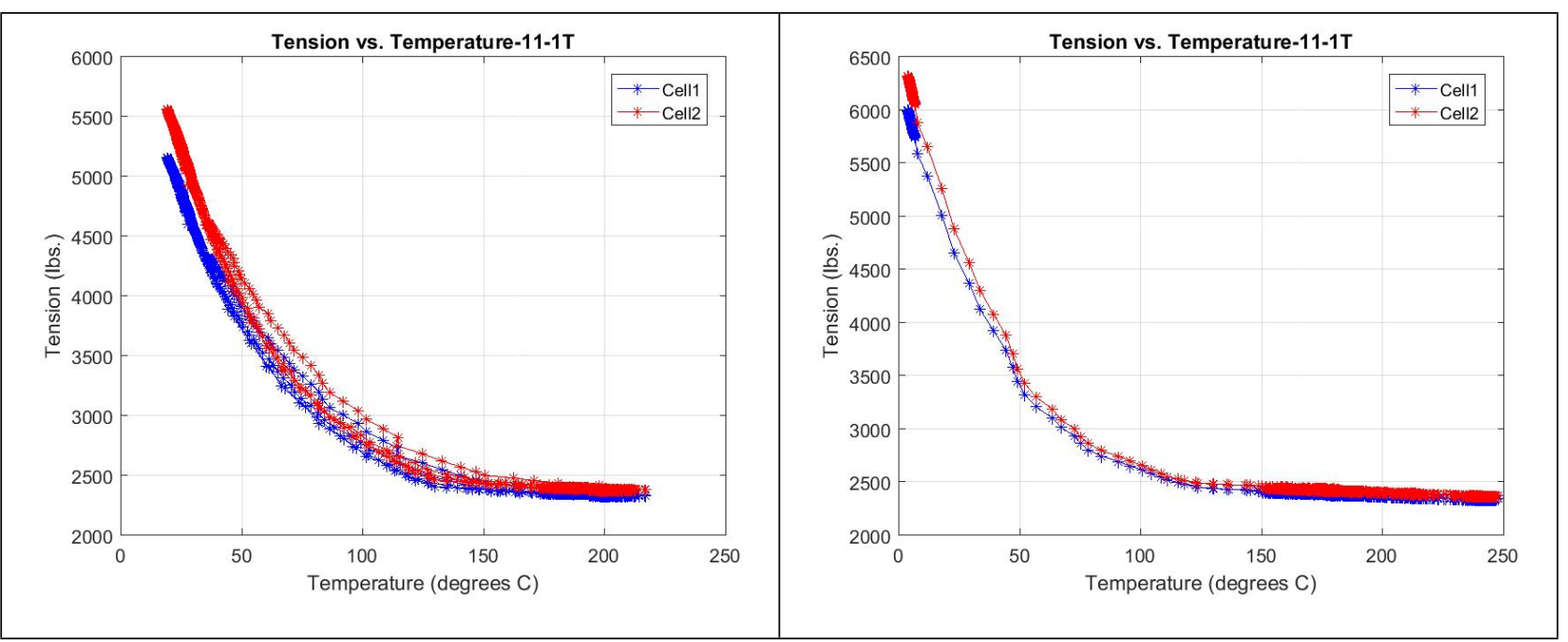

Figure 43. Transition of knee point from thermal aging of channel 11 treeside.

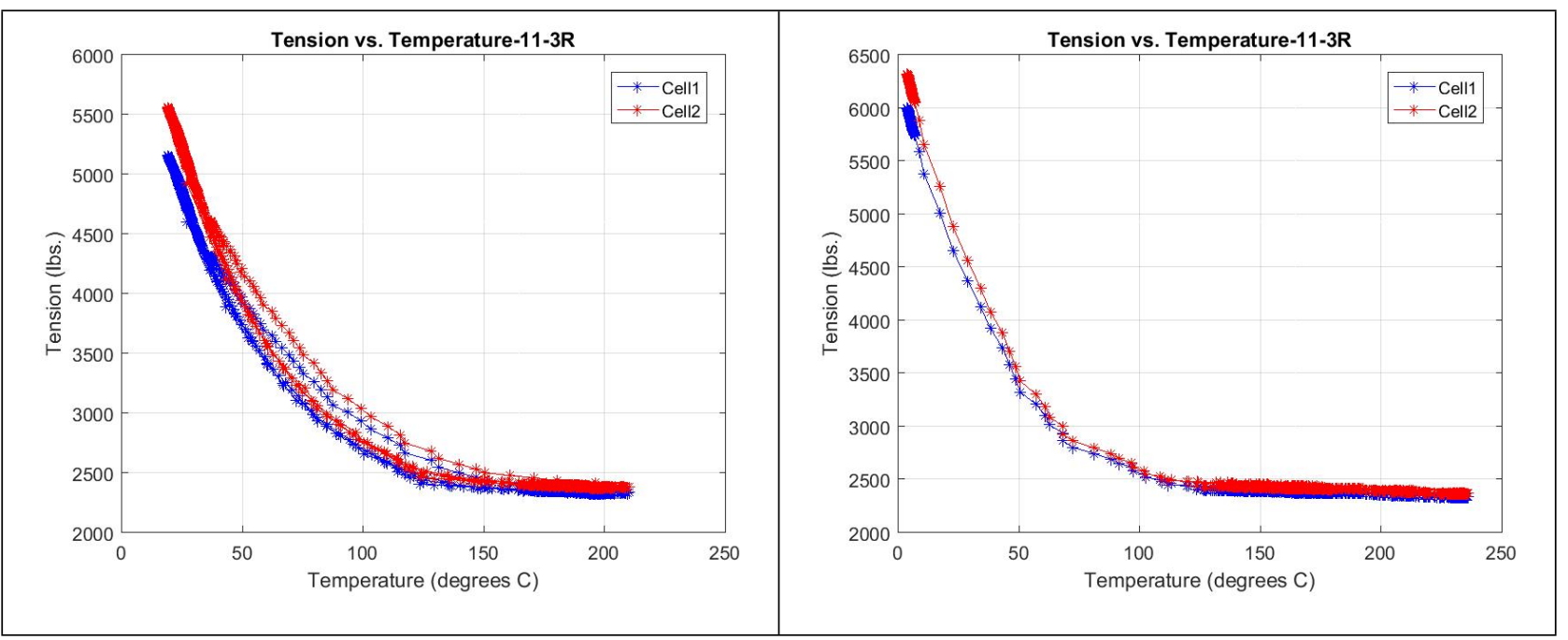

Figure 44. Transition of knee point from thermal aging of channel 11 roadside. 


\section{APPENDIX A. CONTROL SYSTEM FOR THE POWERLINE CONDUCTOR ACCELERATED TEST FACILITY}

The Oak Ridge National Laboratory Powerline Conductor Accelerated Test facility has a long history of testing conductors and acquiring detailed measurements for conductors in the field. The system currently is controlled by a set of codes in Visual Basic on a desktop computer. There are plans to upgrade this control system to a LabVIEW-based architecture in the future to support further development. Figure A.1 shows the current data acquisition system, which can accommodate up to 128 thermocouple measurements, current and voltage measurements, conductor sag, conductor tension, and weather conditions. Each of these samples is polled, averaged, and then logged at one sample per minute.

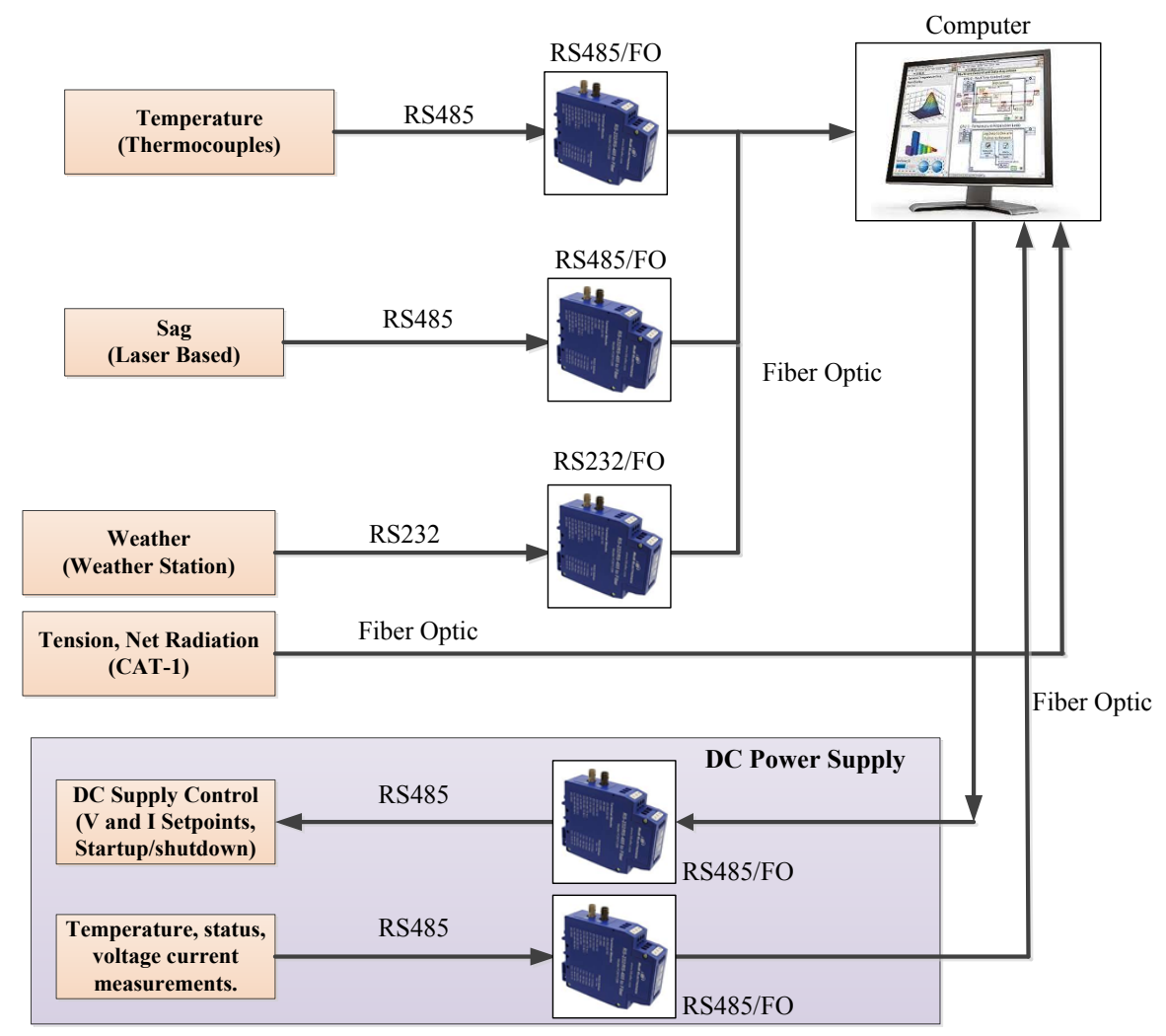

Figure A.1. Current operating system for the Powerline Conductor Accelerated Test facility. 



\section{APPENDIX B. THERMOCOUPLE CHANNELS AND LOCATIONS}

Table B.1. Thermocouple attachment channels and locations

\begin{tabular}{|c|c|c|c|}
\hline Channel & Location & Channel & Location \\
\hline $2-1 \mathrm{~T}$ & First Tower & $11-1 \mathrm{~T}$ & $750 \mathrm{ft}$ \\
\hline $2-2 \mathrm{~T}$ & First Tower & $11-2 \mathrm{~T}$ & $750 \mathrm{ft}$ \\
\hline $2-3 \mathrm{~T}$ & First Tower & $11-3 R$ & $750 \mathrm{ft}$ \\
\hline $2-4 \mathrm{~T}$ & First Tower & $11-4 R$ & $750 \mathrm{ft}$ \\
\hline $3-1 R$ & First Tower & $12-1 \mathrm{~T}$ & $900 \mathrm{ft}$ (midspan) \\
\hline $3-2 \mathrm{R}$ & First Tower & $12-2 \mathrm{~T}$ & $900 \mathrm{ft}$ (midspan) \\
\hline $3-3 R$ & First Tower & $12-3 R$ & $900 \mathrm{ft}$ (midspan) \\
\hline $3-4 R$ & First Tower & $12-4 R$ & $900 \mathrm{ft}$ (midspan) \\
\hline $5-1 \mathrm{~T}$ & $150 \mathrm{ft}$ & $13-1 \mathrm{~T}$ & $900 \mathrm{ft}$ (midspan) \\
\hline $5-2 \mathrm{~T}$ & $150 \mathrm{ft}$ & $13-2 \mathrm{~T}$ & $900 \mathrm{ft}$ (midspan) \\
\hline $5-3 R$ & $150 \mathrm{ft}$ & $13-3 R$ & $900 \mathrm{ft}$ (midspan) \\
\hline $5-4 \mathrm{R}$ & $150 \mathrm{ft}$ & $13-4 R$ & $900 \mathrm{ft}$ (midspan) \\
\hline $6-1 \mathrm{~T}$ & $300 \mathrm{ft}$ (midspan) & $14-1 \mathrm{~T}$ & $1050 \mathrm{ft}$ \\
\hline $6-2 \mathrm{~T}$ & $300 \mathrm{ft}$ (midspan) & $14-2 \mathrm{~T}$ & $1050 \mathrm{ft}$ \\
\hline $6-3 R$ & $300 \mathrm{ft}$ (midspan) & $14-3 R$ & $1050 \mathrm{ft}$ \\
\hline $6-4 R$ & $300 \mathrm{ft}$ (midspan) & $14-4 \mathrm{R}$ & $1050 \mathrm{ft}$ \\
\hline $7-1 \mathrm{~T}$ & $300 \mathrm{ft}$ (midspan) & $15-1 \mathrm{~T}$ & $1200 \mathrm{ft}$ (Third Tower) \\
\hline $7-2 \mathrm{~T}$ & $300 \mathrm{ft}$ (midspan) & $15-2 \mathrm{~T}$ & $1200 \mathrm{ft}$ (Third Tower) \\
\hline $7-3 R$ & $300 \mathrm{ft}$ (midspan) & $15-3 \mathrm{~T}$ & $1200 \mathrm{ft}$ (Third Tower) \\
\hline $7-4 \mathrm{R}$ & $300 \mathrm{ft}$ (midspan) & $15-4 \mathrm{~T}$ & $1200 \mathrm{ft}$ (Third Tower) \\
\hline $8-1 \mathrm{~T}$ & $450 \mathrm{ft}$ & $15-5 R$ & $1200 \mathrm{ft}$ (Third Tower) \\
\hline $8-2 \mathrm{~T}$ & $450 \mathrm{ft}$ & $15-6 \mathrm{R}$ & $1200 \mathrm{ft}$ (Third Tower) \\
\hline $8-3 R$ & $450 \mathrm{ft}$ & $15-7 \mathrm{R}$ & $1200 \mathrm{ft}$ (Third Tower) \\
\hline $8-4 \mathrm{R}$ & $450 \mathrm{ft}$ & $15-8 \mathrm{R}$ & $1200 \mathrm{ft}$ (Third Tower) \\
\hline $9-1 \mathrm{~T}$ & & $16-1 \mathrm{E}$ & $1200 \mathrm{ft}$ (Third Tower) \\
\hline $9-2 \mathrm{~T}$ & & $16-2 \mathrm{E}$ & $1200 \mathrm{ft}$ (Third Tower) \\
\hline $9-3 R$ & & $16-3 \mathrm{E}$ & $1200 \mathrm{ft}$ (Third Tower) \\
\hline $9-4 \mathrm{R}$ & & $16-4 \mathrm{E}$ & $1200 \mathrm{ft}$ (Third Tower) \\
\hline $10-1 \mathrm{~T}$ & $600 \mathrm{ft}$ (Second Tower) & $16-5 \mathrm{E}$ & $1200 \mathrm{ft}$ (Third Tower) \\
\hline $10-2 \mathrm{~T}$ & $600 \mathrm{ft}$ (Second Tower) & $16-6 \mathrm{E}$ & $1200 \mathrm{ft}$ (Third Tower) \\
\hline $10-3 R$ & $600 \mathrm{ft}$ (Second Tower) & $16-7 \mathrm{E}$ & $1200 \mathrm{ft}$ (Third Tower) \\
\hline $10-4 \mathrm{R}$ & $600 \mathrm{ft}$ (Second Tower) & $16-8 \mathrm{E}$ & $1200 \mathrm{ft}$ (Third Tower) \\
\hline
\end{tabular}


